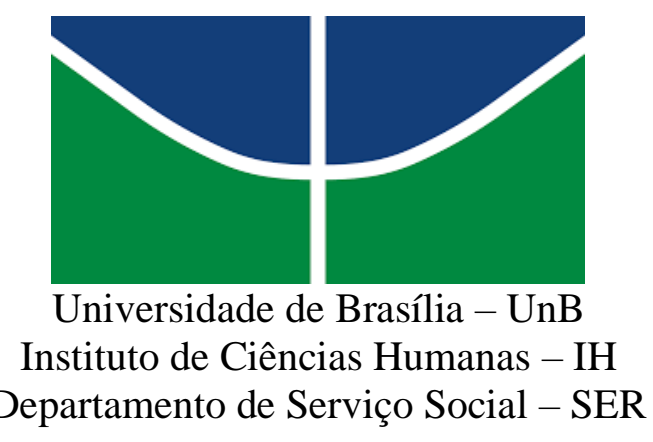

SERVIÇO DE ESTUDOS E ATENÇÃO A USUÁRIOS DE ÁLCOOL E OUTRAS DROGAS (SEAD): A ADESÃO SOB A PERSPECTIVA DOS USUÁRIOS DO HOSPITAL UNIVERSITÁRIO DE BRASÍLIA

CAIO HENRIQUE INÁCIO FERREIRA

Brasília-DF 
CAIO HENRIQUE INÁCIO FERREIRA

\section{SERVIÇO DE ESTUDOS E ATENÇÃO A USUÁRIOS DE ÁLCOOL E OUTRAS DROGAS (SEAD): A ADESÃO SOB A PERSPECTIVA DOS USUÁRIOS DO HOSPITAL UNIVERSITÁRIO DE BRASÍLIA}

Trabalho de Conclusão de Curso apresentado ao Departamento de Serviço Social da Universidade de Brasília - UnB como requisito parcial à obtenção do título de Bacharel em Serviço Social.

Orientadora: Prof. ${ }^{\text {. }}$ Dr ${ }^{\mathrm{a}}$. Karen Santana de Almeida Vieira. 


\title{
SERVIÇO DE ESTUDOS E ATENÇÃO A USUÁRIOS \\ DE ÁlCOOL E OUTRAS DROGAS (SEAD): A ADESÃO SOB A PERSPECTIVA DOS USUÁRIOS DO HOSPITAL UNIVERSITÁRIO DE BRASÍLIA
}

\begin{abstract}
Trabalho de conclusão de curso apresentado ao Departamento de Serviço Social da Universidade de Brasília para a obtenção do título de Bacharel em Serviço Social.
\end{abstract}

Aprovado em:___ / / / 2019

BANCA EXAMINADORA

Prof. Dr ${ }^{\mathrm{a}}$. Karen Santana de Almeida Vieira

(SER/UnB) (Orientadora)

Prof ${ }^{\mathrm{a}}$. Mestre Marlene de Jesus Silva Santos

(Membro interno do SER/UnB)

Mestre Jamila Zgiet Rodrigues Santos

(Membro externo ao SER/ UnB) 
Dedico este trabalho aos usuários e profissionais do SEAD: que a intervenção seja sempre crítica, ampliada e qualificada. 


\section{AGRADECIMENTOS}

A Deus, porque dele, e por Ele, e para Ele, são todas as coisas.

À minha mãe e avó por tanto carinho, amor e afeto. Por um convívio recheado de apoio, algumas desarmonias e muito companheirismo. Sem vocês nada seria possível.

As minhas tias e tios, principalmente a Tia Cleide e o Tio Kaká. Obrigado por todo apoio, todo conselho, todo afeto e presença, vocês são incríveis.

As minhas primas e primos, eu sou porque nós somos. Não ouso nomeá-los, sob o risco de esquecer alguém. Minhas reflexões têm um pouco de vocês porque em mim tem muito de cada um.

As amigas e amigos. Em especial, a amiga Malu, por toda paciência, por todo amor e por todos os conselhos. Amo-te.

À "Lauriete", amiga da UnB, pela paciência com a minha ignorância acerca das regras da ABNT, que tanto me ajudou nas noites de leituras e nos dias de formatação deste trabalho.

À minha orientadora, Prof. ${ }^{a}$ Dr $^{\mathrm{a}}$. Karen Santana de Almeida Vieira por ter confiado e acreditado em mim e também pelo apoio dado no dia a dia;

À Assistente Social Cláudia Merçon de Vargas pelo constante incentivo e ensinamentos durante e após os estágios supervisionados obrigatórios, e às assistentes sociais residentes do SEAD que colaboraram com a produção deste trabalho;

À toda equipe e os pacientes do SEAD, em especial a Dirce e a Fabiane que tanto me ajudaram na coleta de dados;

À Beatriz Leal, Gabriela Vieira e Laura Oliveira, presentes que a UnB me deu, que enfrentaram comigo todas as lutas e glórias da vida acadêmica. Certamente os laços construídos serão mantidos e levados comigo, o que demonstra que cultivamos uma amizade para além da vida universitária. 
"A condição de sujeito de direitos não pode ser anulada, reduzida ou ignorada em decorrência do uso de psicoativos, independentemente do caráter lícito ou ilícito da substância consumida". (BRITES, 2014) 


\section{RESUMO}

O uso e o abuso de substâncias psicoativas tornaram-se um grave problema de saúde pública, tanto pelas suas consequências na vida do usuário como pelas suas consequências no meio social, sendo o processo de adesão ao tratamento um grande desafio. Essa monografia tem como objetivo geral analisar os fatores de adesão que interferem no processo de tratamento dos usuários do Serviço de Estudos e Atenção a usuários de Álcool e outras Drogas (SEAD) sob a perspectiva dos próprios sujeitos e a partir dos limites e das possibilidades do trabalho do assistente social frente à problemática do álcool e outras drogas no contexto da Questão Social. A pesquisa utiliza métodos de coleta e de análise dos dados da pesquisa qualitativa. Os dados foram coletados por meio de um grupo focal com 9 pacientes, usuários de álcool e outras drogas, em tratamento no SEAD do Hospital Universitário de Brasília (HuB) e com as Assistentes Sociais do serviço durante o estágio supervisionado deste pesquisador no período de abril a dezembro de 2018. Dentre alguns dos resultados alcançados, percebeu-se que no que diz respeito a influência dos fatores de adesão no processo de tratamento: sob a ótica dos pacientes é imprescindível destacar o apoio familiar compreendido como um apoio que se dá em todo o processo de tratamento, além de profissionais comprometidos com a temática de álcool e outras drogas; a vontade própria do paciente em mudar sua situação; e um tratamento humanizado e sem estigmas por parte dos profissionais de saúde, aqui inclusive, dos assistentes sociais. Espera-se com este estudo fomentar, no âmbito da academia, a importância da temática de álcool e outras drogas no Serviço Social.

PALAVRAS-CHAVE: Uso de álcool, Serviço Social, Substâncias Psicoativas, Fatores de adesão. 


\begin{abstract}
The use and abuse of psychoactive substances has become a serious public health problem, both for its consequences on the user's life and for its consequences to the social environment, making the adherence process to the treatment a great challenge. The general objective of this monograph is analyze the adhesion factors that interfere in the treatment process of the users the Service Attention Users of Alcohol and other drugs (SEAD) from their own perspective and before the limits and possibilities of the social worker's job, facing the alcohol and other drugs in the Social Question context. The research study is qualitative and uses data collection and analysis methods. Data was collected through a focus group with 9 patients, users of alcohol and other drugs, undergoing treatment in SEAD at the University Hospital of Brasília $(\mathrm{HuB})$, together the Social Workers of the service during all supervised practice of this researcher, from April to December 2018. Among the results achieved, it was noticed that regarding the influence of the adherence factors in the treatment process: from the patients point of view it is essential to highlight the family support, understood as a support that occurs throughout the treatment process, besides professionals engaged to the theme of alcohol and other drugs; the patient's own willingness to change their situation; and a humanized non-stigmatized treatment by health professionals, including social workers. It is expected to promote the importance of alcohol and other drugs inside of Social Work within the scope of academy.
\end{abstract}

KEYWORDS: Alcohol use, social work, psychoactive substances, adhesion factors. 


\section{LISTA DE ABREVIATURAS E SIGLAS}

CAPS - Centro de Atenção Psicossocial

CAPS ad - Centro de Atenção Psicossocial álcool e outras drogas

CFESS - Conselho Federal de Serviço Social

DF - Distrito Federal

SUS - Sistema Único de Saúde

SEAD - Serviço de Estudos e Atenção a usuários de Álcool e outras Drogas

UnB - Universidade de Brasília

HuB - Hospital Universitário de Brasília

OMS - Organização Mundial da Saúde

SNC - Sistema Nervoso Central

TCLE - Termo de Consentimento Livre e Esclarecido

SPA's - Substâncias Psicoativas

GF - Grupo Focal

MRSB - Movimento de Reforma Sanitária Brasileira

PNAD - Política Nacional sobre Drogas

EBSERH - Empresa Brasileira de Serviços Hospitalares

CEBES - Centro Brasileiro de Estudo de Saúde

RSB - Reforma Sanitária Brasileira

ESF - Estratégia de Saúde da Família

PTS - Plano Terapêutico Singular

RAPS - Rede de Atenção Psicossocial

PNH- Política Nacional de Humanização 


\section{SUMÁRIO}

INTRODUÇÃO. 9 a 17

CAPÍtulo 1 - A POLÍtica de SAÚde, A SAÚdE MENTAL E SUBSTÂnCiAS PSICOATIVAS

1.1 História da política de saúde e nuances da política de saúde mental 19 a 27

1.2 As implicações das substâncias psicoativas na saúde mental .27 a 32

\section{CAPÍTULO 2 - O USO DE SUBSTÂNCIAS PSICOATIVAS E O SERVIÇO SOCIAL: CONCEITOS E DETERMINANTES SOCIAIS DA SAÚDE}

2.1 Uso de Álcool, outras drogas e seus conceitos .34 a 40

2.2 Substâncias psicoativas e o Serviço Social: uma contextualização com os determinantes sociais da saúde 40 a 43

CAPÍTULO 3 - DEPENDÊNCIA DE SUBSTÂNCIAS PSICOATIVAS E OS FATORES DE ADESÃO: SOB O OLHAR DOS USUÁRIOS DO HOSPITAL UNIVERSITÁRIO DE BRASÍLIA

3.1 Hospital Universitário de Brasília - HuB .45 a 47

3.2 O Serviço de Estudos e Atenção a Usuários de Álcool e outras Drogas - SEAD ... 47 a 49

3.3 Família, força de vontade do usuário e socialização de informações 49 a 50

3.3.1 O perfil do usuário do SEAD 51 a 66

CONSIDERAÇÕES FINAIS .67 a 68

REFERÊNCIAS BIBLIOGRÁFICAS. .69 a 73

ANEXOS .74 a 75 


\section{INTRODUÇÃO}

O presente trabalho constitui-se como pré-requisito necessário para a obtenção do título de Bacharel em Serviço Social pela Universidade de Brasília (UnB) e teve como objetivo analisar os fatores de adesão que interferem no processo de tratamento dos usuários do Serviço de Estudos e Atenção a usuários de Álcool e outras Drogas (SEAD) sob a perspectiva dos próprios usuários e a partir dos limites e das possibilidades do trabalho do assistente social frente à problemática do álcool e outras drogas no contexto da Questão Social.

O principal interesse pelo tema foi sendo construído a partir da experiência de estágio supervisionado em Serviço Social no SEAD. Esta experiência trouxe importantes reflexões sobre o cotidiano do trabalho do assistente social no Hospital Universitário de Brasília (HuB) e alguns questionamentos, dentre eles: Quais são as dificuldades que os pacientes usuários de substâncias psicoativas enfrentam no processo de adesão ao tratamento? Quais são os fatores que interferem nesse processo? Quais são os limites e as possibilidades da intervenção do assistente social frente a esta temática?

No Brasil, país majoritariamente urbano, o problema das drogas encontra reverberação mais forte nas grandes cidades brasileiras, o qual, em diferentes esferas da vida cotidiana, adquire grande seriedade os assuntos concernentes ao consumo alarmante e ao tráfico de drogas. Somado a isso, encontra-se nos noticiários manchetes sobre violência, criminalidade e a ineficiência dos órgãos de Segurança Pública diante dos estragos causados pelo fenômeno das drogas e múltiplas expressões da Questão Social.

Segundo Iamamoto (1999, p. 27), a Questão Social pode ser conceituada como: o conjunto das expressões das desigualdades da sociedade capitalista madura, que têm uma raiz comum: a produção social é cada vez mais coletiva, o trabalho torna-se mais amplamente social, enquanto a apropriação dos seus frutos se mantém privada, monopolizada por uma parte da sociedade.

Nesse sentido, é somente no contexto da sociedade capitalista que a questão das drogas passa a ser objeto de preocupação da sociedade, seja relacionada ao circuito da produção, circulação e concorrência intercapitalista; seja associada ao consumo "problemático" desta mercadoria e aos danos sociais ${ }^{1}$ produzidos em decorrência desse uso e

\footnotetext{
${ }^{1}$ Entendemos como "danos sociais" as diversas formas de violências sofridas e/ou praticadas pelos usuários de drogas, em decorrência do uso problemático como as várias manifestações da violência doméstica, os rompimento dos vínculos familiares e comunitários, o isolamento social, a situação de rua, a exploração sexual de crianças e adolescentes, a comercialização do corpo feminino em troca da droga, a criminalidade aquisitiva,
} 
da relação estabelecida pela sociedade com esta prática. Por esse ângulo, na sociedade moderno-contemporânea a "questão das substâncias psicoativas" se materializa como uma das expressões da questão social, aqui entendida como a "expressão politizada das desigualdades sociais" produzidas pela sociabilidade capitalista (MOTA, 2009).

Em consonância com esses pressupostos, e segundo os autores Santos \& Freitas (2012), com quem concordamos na análise, a problemática do uso de drogas no Brasil, entendida como uma das expressões da Questão Social, tem sido alvo de esforços diferenciados por parte do Governo, da Sociedade Civil, das empresas privadas e de inúmeras outras organizações.

$\mathrm{Na}$ atualidade, têm-se buscado aprimorar estratégias que não se estanquem somente em solucionar as situações geradas pelo uso de substâncias psicoativas (SPA's) (dependência química, situação de pobreza e desigualdade social, envolvimento em práticas ilegais), mas se preocupam ao materializar ações que tenham como objetivo fundamental a prevenção ao uso.

Ainda conforme reflexões dos autores supracitados (2012) essa busca se estabelece pela imprescindibilidade observada em estudos e em pesquisas das mais diversas áreas do conhecimento, que apontam para o desafio de se desenvolverem ações que tenham como foco as atitudes preventivas, visto que práticas como a criminalização do usuário, a repressão pontual e limitada, desenvolvidas até recentemente na história brasileira, não tiveram sua eficácia constatada na redução dos casos de dependência de drogas e todas as situações advindas dela.

A Organização Mundial da Saúde (OMS) considera que, em linguagem informal, o termo "droga", em geral, remete-se estritamente a substâncias psicoativas e, constantemente, a drogas ilegais. Por sua vez, as chamadas drogas psicoativas são as que têm princípio ativo capaz de estimular, deprimir ou perturbar a mente humana, sejam elas lícitas ou ilícitas desorganizando o Sistema Nervoso Central (SNC) e provocando desorientação das funções cerebrais.

Dessa maneira, neste trabalho, o emprego do termo "droga" algumas vezes poderá ser substituído por "substâncias psicoativas", pois compreende-se que os dois termos têm o mesmo significado, isto é, toda substância que, introduzida no organismo, por qualquer via de administração, altera de algum modo o SNC e pode criar dependência física, psicológica ou ambas. Porém, tem-se o entendimento de que "droga" apesar de ter o mesmo significado e

além da disseminação de doenças infecto contagiosas (DST's/AIDS, tuberculose, hepatites) e do desenvolvimento de transtornos mentais advindos do uso abusivo como depressão, transtornos de ansiedade e psicoses. (Albuquerque et.al, 2013) 
utilizado diversas vezes no decorrer do trabalho por uma questão estilística, tem de ser evitada uma vez que imprime um caráter estigmatizante. Por isso opta-se por colocar o termo entre aspas.

Conforme Brites (2014) o termo "droga" tem sido usado de maneira inadvertida, contribuindo com visões mistificadoras sobre o uso e os usuários de psicoativos, bem como com a reprodução acrítica de juízos de valores estigmatizantes. Nessa direção, a autora aduz que:

O termo droga tem contribuído também para naturalizar um tratamento desigual entre usuárias/os de psicoativos, já que as pessoas que usam psicoativos lícitos são geralmente tratadas como sujeitos de direitos, ao passo em que, às/aos usuárias/os de psicoativos ilícitos, é relegada a condição culturalmente condenável de viciadas e drogadas. Essa desigualdade de tratamento, associada ao termo droga, longe de ser um preciosismo linguístico, produz impactos sociais que não podem ser minimizados. (BRITES, 2014)

Os estudos do Escritório das Nações Unidas sobre Drogas e Crime do ano de 2014 evidenciaram que cerca de 243 milhões de pessoas, número que se equipara a $5 \%$ da população, faz o uso de substâncias psicoativas ilícitas e, desses, 0,6\% desenvolve a dependência de tais substâncias, ocasionando acentuado abalo na vida individual, familiar, social e ocupacional.

Já em 2015, o Relatório Mundial sobre Drogas, do Escritório das Nações Unidas sobre Drogas e Crimes estimou que um total de 246 milhões de pessoas - um pouco mais do que $5 \%$ da população mundial com idade entre 15 e 64 anos - tenha feito uso de drogas ilícitas uma vez na vida e cerca de 27 milhões de pessoas fazem uso intensivo de drogas, das quais quase a metade são pessoas que usam drogas injetáveis (UNITED NATIONS OFFICE ON DRUGS AND CRIME, 2015).

Vale ressaltar que antes mesmo da publicação destes estudos, o Estado Brasileiro reconheceu legalmente com a aprovação da Política Nacional sobre Drogas (27 de outubro de 2005), a conveniência de se conjugar esforços para que as ações relativas à problemática do uso de substâncias psicoativas tenham o seu principal enfoque voltado para a prevenção.

Considerando que o uso de substâncias psicoativas está presente em diferentes culturas com peculiaridades singulares ao longo da história, faz-se necessário salientar que atualmente, essa questão ganhou características específicas e vem sendo compreendida como uma pauta complexa e que requer ações de diversos setores, tais como a Saúde, Assistência Social, Justiça, etc. 
Nessas circunstâncias, segundo as autoras Veloso e Abreu (2004), em um contexto em que germina o horror e o preconceito, surge o desejo de banir as drogas da sociedade. Imagina-se, assim, um "mundo puro", "ordenado", "limpo", isto é, sem drogas². Contudo, alguns estudos já apontam a impossibilidade de se viver em um mundo sem drogas. Bucher (1992) argumenta que o consumo de drogas se constitui numa "prática humana milenar e universal" (1992, p.27) e, portanto, considera fantasiosa a ideia de uma "terra santa livre de tóxicos" (1997, p.27).

Destarte, o consumo de drogas deve ser percebido como parte da realidade cotidiana pois, apesar de estar presente em toda a história da humanidade, a droga é um produto inerte e "o mal não está no produto em si, mas na forma como nos servimos dele" (ACSELRAD 2000, p.187).

Desta forma, cabe-nos interpretar que, para apreender o fenômeno do uso de drogas e suas diferentes expressões, torna-se imprescindível que este seja entendido não como um mal externo à sociedade, mas sim como fenômeno por ela gestado, num contexto sócio histórico, econômico e também cultural.

Assim, na tentativa de fazer desse panorama o menos preocupante possível, o tratamento para abuso ou dependência de substâncias psicoativas requer diversas intervenções terapêuticas ${ }^{3}$, psicoterapêuticas e sociais, fundamentado em uma equipe interdisciplinar ${ }^{4}$ que considere o indivíduo em sua totalidade, projetado à reabilitação e à reinserção social desse indivíduo.

À vista disso, segundo as literaturas realizadas durante a elaboração deste trabalho e as reflexões vivenciadas no estágio, é possível afirmar que o acolhimento e a vinculação ao tratamento de usuários de substâncias psicoativas torna imperativo para a manutenção da adesão, uma vez que dela depende para o sucesso da proposta de tratamento, a redução de possíveis doenças e agravos, a motivação para a reabilitação, a prevenção de lapsos e as recaídas e, sobretudo, a (re) inserção social. (SANTOS \& FREITAS, 2012)

É de suma importância esclarecer que Santos \& Freitas (2012) dissertam que é necessário considerar que o Serviço Social têm nas Políticas Públicas um espaço privilegiado para o exercício profissional e as ações da Política Nacional sobre Drogas podem também

\footnotetext{
${ }^{2}$ Destaques do autor

${ }^{3}$ Para um maior aprofundamento sobre a questão polêmica no Serviço Social acerca de práticas terapêuticas, consultar: GUIMARÃES (2013).

${ }^{4}$ Segundo Costa (2007) a interdisciplinaridade não pode se constituir nos serviços de saúde como modismo ou "camisa de força" para os trabalhadores. Deve ser uma construção reflexiva coletiva que considere e problematize as práticas cotidianas e as relações de saber e de poder em seu interior a fim de construir práticas mais efetivas e formas de trabalho mais satisfatórias para trabalhadores e usuários.
} 
configurar-se como possibilidades de trabalho efetivo na defesa de direitos, principalmente, como partícipe nesse conjugar de esforços objetivando a prevenção ao uso de drogas.

Nessa perspectiva, a inserção do profissional de Serviço Social nesses lócus pode ser compreendida para além da possibilidade de ocupação profissional, mas como dever de uma profissão, que tem no seu caráter ontológico o compromisso ético da defesa e do aprofundamento da cidadania (SANTOS \& FREITAS, 2012).

Lembremos ainda que o Serviço Social, enquanto profissão que detém como chão comum a história da sociedade, tem a Questão Social como fundamento da especialização do seu trabalho. Logo, trabalhar com as especificidades das múltiplas expressões da Questão Social que se apresentam na sociedade contemporânea é tarefa que se encontra no âmbito do exercício profissional do assistente social também no lócus da temática do uso de álcool e outras drogas (IAMAMOTO, 2001).

Segundo Iamamoto (2001) um dos maiores desafios que o assistente social vive na contemporaneidade é desenvolver sua capacidade de decifrar a realidade e de construir propostas de trabalho criativas e capazes de preservar e efetivar os direitos, a partir de demandas emergentes do cotidiano (IAMAMOTO 2001). Por todos esses motivos, o fenômeno das drogas pode ser, então, compreendido como uma das expressões da Questão Social no cenário atual, incorporando a necessidade de repensar as ações do assistente social nesse contexto, apesar da referida autora não ter feito esse paralelo de compreensão.

De acordo com o Guia Estratégico para o Cuidado de Pessoas com Necessidades Relacionadas ao Consumo de Álcool e Outras Drogas: Guia AD (2015) do Ministério da Saúde, a busca e a adesão a serviços de atenção e cuidado a pessoas usuárias de álcool, crack e outras drogas têm, cada vez mais, se mostrado um grande desafio, porque isso envolve processos complexos. A OMS define conceitualmente a adesão como "[...] o grau em que o comportamento de uma pessoa - tomar o medicamento, seguir um regime alimentar e/ou executar mudanças no estilo de vida - corresponde às recomendações acordadas com um prestador de cuidados de Saúde". (OMS, 2003)

Por outro lado, alguns teóricos conceituam adesão como se manter abstinente em relação à substância utilizada. Contudo, neste trabalho a compreensão é de que tal conceito pode ir além e sugere que a adesão a um tratamento envolve o estabelecimento de vínculo entre usuário do serviço e a equipe de saúde, de forma que exista compromisso recíproco nas atividades integradas ao tratamento e, resultante disso, o favorecimento de mudanças no comportamento em relação ao uso da droga, e não necessariamente uma ruptura automática do uso da substância psicoativa. 
O processo de adesão ao tratamento inclui questões inerentes ao sujeito, sua percepção sobre a questão do uso e suas relações com a equipe que o assiste, seu grau de engajamento e decisão na elaboração do Plano Terapêutico Singular (PTS), bem como a garantia da oferta e qualificação da assistência prestada e o apoio recebido dentro e fora dos serviços especializados, sobretudo, no SEAD, do Hospital Universitário de Brasília.

Levando em consideração toda a problemática ora apresentada, e considerando os desafios e a complexidade postas pelo fenômeno do uso de substâncias psicoativas, faz-se necessário reafirmar que o tratamento especializado é importante. Contudo, sabe-se que devido a tal complexidade, uma das questões cruciais que deve ser considerada é no que se refere a adesão ao tratamento, visto que muitos são os fatores que influenciam a adesão. Por todos esses motivos, o objetivo geral e específico dessa pesquisa se descreve abaixo:

- OBJETIVO GERAL: Analisar os fatores de adesão que interferem no processo de tratamento dos usuários do SEAD sob a perspectiva dos próprios sujeitos e a partir dos limites e das possibilidades do trabalho do assistente social frente à problemática do álcool e outras drogas no contexto da Questão Social

- OBJETIVOS ESPECÍfICOS: 1) Analisar a intervenção do Assistente Social frente à questão do álcool e outras drogas no SEAD/HuB; 2) Analisar os dados da ficha de acolhimento dos usuários com vistas a caracterizar: sexo, escolaridade, situação conjugal, tipos de substâncias consumidas e apoio familiar; 3) Identificar fatores que influenciam a adesão.

Para tal, adotou-se como metodologia de pesquisa o método qualitativo, tanto para a coleta dos dados quanto para a análise. No método qualitativo, utilizou-se como principal instrumento de coleta o enfoque no Grupo Focal (GF) com a finalidade de explorar o espaço dando respostas às questões levantadas pela própria pesquisa e baseando-se no relato da socióloga Minayo (2002) que sobre a pesquisa qualitativa discorre:

\footnotetext{
A pesquisa qualitativa responde as questões muito particulares. Ela se preocupa, nas ciências sociais, com um nível de realidade que não pode ser quantificado. Ou seja, ela trabalha com o universo de significados, motivos, aspirações, crenças, valores e atitudes, o que corresponde a um espaço mais profundo das relações dos processos e dos fenômenos que não podem ser reduzidos à operacionalização de variáveis. (MINAYO, 2002, p. 21-22)
}

Segundo Minayo (2008) a abordagem qualitativa, aprofunda-se nas ações e relações humanas um lado perceptível que não é, por sua vez, captado por equações, médias e estatísticas, e argumenta que como a pesquisa qualitativa trabalha geralmente com pessoas e 
com suas criações, esses sujeitos de pesquisa devem ser compreendidos como atores sociais, respeitados em suas opiniões, crenças e valores.

Por esses motivos elencados acima, e devido ao objetivo desta pesquisa a abordagem qualitativa se faz aqui nossa escolha e a melhor opção considerando que os dados de percepção obtidos nos discursos dos sujeitos são de extrema importância, pois a fala é repleta de condições estruturais, de sistemas de valores, normas e símbolos, sendo assim tão rica e reveladora (MINAYO, 2008, p. 204).

O grupo focal, por sua vez, é aplicado como técnica por pesquisador que tem como objetivo coletar informações sobre um determinado tema específico por meio da discussão participativa entre os sujeitos de pesquisa, reunidos em um mesmo local e durante certo período de tempo. Como técnica, ocupa uma posição intermediária entre a observação participante e as entrevistas em profundidade. Pode ser caracterizada também como um recurso para compreender o processo de construção das percepções, atitudes e representações sociais de grupos humanos (VEIGA \& GONDIM, 2001).

Ainda segundo Veiga e Gondim (2001), a questão ética merece atenção especial do pesquisador para delinear seu projeto de investigação. Trata-se de garantir a privacidade dos participantes. Além disso, o tema pode vir a exigir posicionamentos pessoais que serão revelados a pessoas desconhecidas. Discutir o consumo de álcool e de outras drogas, por exemplo, pode colocar os participantes em uma situação delicada e o moderador deve dar sinais claros de que providências estão sendo tomadas para preservar a identidade pessoal na divulgação dos resultados.

Considerando esses aspectos, Iervolino \& Pelicioni (2001) destacam que a coleta de dados por meio do grupo focal tem como uma de suas maiores riquezas basear-se na tendência humana de formar opiniões e atitudes na interação com outros indivíduos. As pessoas, em geral, precisam ouvir as opiniões dos outros antes de formar as suas próprias, e constantemente mudam de posição (ou fundamentam melhor sua posição inicial) quando expostas à discussão em grupo. É exatamente esse processo que o grupo focal tenta captar.

Nesse sentido, os dados foram coletados pelo pesquisador/estudante no decorrer do Estágio em Serviço Social realizado no período de abril a dezembro de 2018 e teve a participação e supervisão de todo o processo pelas Supervisoras de Estágios. Foi realizado um grupo focal, com duração de uma hora, em uma sala do SEAD, sendo datas e horário acordados durante o levantamento junto aos potenciais participantes. Os 9 sujeitos de pesquisa foram escolhidos de forma intencional e que atendiam aos critérios do objetivo da pesquisa: Pacientes que deram entrada ao SEAD, tendo em comum o fato de serem usuários 
de alguma substância psicoativa e que aderiram ao tratamento (vieram ao acolhimento e deram continuidade).

A coordenação do GF foi composta por um moderador (estagiário e estudante de Serviço Social do SEAD e autor do trabalho) e duas observadoras, integrantes da equipe do SEAD, Assistente Social e a estagiária de Serviço Social.

Os sujeitos receberam as informações sobre os objetivos do estudo sendo-lhes garantido o sigilo e o anonimato ${ }^{5}$. Todos assinaram o Termo de Consentimento Livre e Esclarecido (TCLE) estruturado, em duas vias, que ficaram uma com o pesquisador e a outra com o usuário, que visa garantir ao participante da pesquisa os esclarecimentos no decorrer de todo o processo da pesquisa a ser realizada e de maneira que, ao tomar sua decisão não traga nenhum constrangimento/e ou prejuízo.

No entanto, cabe mencionar, que embora o autor tivesse a pretensão de submeter o trabalho no comitê de ética, a presente pesquisa não foi submetida uma vez que os prazos e o rigor dos trâmites burocráticos inviabilizaram tal ação. Além do fato de que o CEP não analisa projetos que já tenham iniciado a coleta de informações ou de dados. Considerando isso, o parágrafo único do artigo 1 da Resolução 510/2016 da Comissão Nacional de Ética em Pesquisa (CONEP) diz que alguns estudos não precisam passar pelo CEP:

Parágrafo único. Não serão registradas nem avaliadas pelo sistema CEP/CONEP:

I - Pesquisa de opinião pública com participantes não identificados;

$[\ldots]$

$[\ldots\}$

VII - pesquisa que objetiva o aprofundamento teórico de situações que emergem espontânea e contingencialmente na prática profissional, desde que não revelem dados que possam identificar o sujeito. [grifo nosso]

De acordo com inciso VII e tendo em conta que os dados da pesquisa foram coletados em período de estágio obrigatório, e com os pacientes que o pesquisador esteve acompanhando durante todo o percurso de estágio, e que o objeto de pesquisa são "os fatores de adesão no processo de tratamento dos usuários de álcool e outras drogas é possível afirmar que a ideia de pesquisar o tema, é fruto de inquietações do autor em campo, onde ele constantemente refletia quais eram os fatores que influenciam na adesão dos pacientes.

\footnotetext{
${ }^{5}$ Como forma de garantir o anonimato e resguardar o sigilo dos participantes, todas as vezes que se fizerem necessárias citações e ou exposições das falas, estas serão referenciadas como: Usuário 01, Usuário 02 [...] Assistente social 01,02, não tendo ligação com a ordem cronológica de execução das falas, mas com numeração aleatória registrada pelo estudante-pesquisador de maneira a reforçar a preservação das identidades, conforme proposto por Creswell (2010).
} 
Além disso, faz-se necessário salientar que segundo Oliveira e Guedes (2013), a observação dos cuidados éticos na coleta de dados e na divulgação dos resultados de uma pesquisa previne o desrespeito aos direitos dos participantes das pesquisas, especialmente se eles estiverem em situação de vulnerabilidade (OLIVEIRA e GUEDES, 2013).

Para atender a segunda parte do objetivo geral referente aos limites e as possibilidades da atuação do assistente social, foi aplicado um questionário com algumas das assistentes sociais do SEAD. A intenção foi manter a homogeneidade dos dados pela mesma instrumento que foi o questionário.

Além do mais, foi empreendida uma revisão bibliográfica especializada sobre a Questão Social e a problemática das Drogas, Políticas de Álcool e Saúde Mental bem como estudos que abordavam sobre os fatores de adesão a tratamento de dependência de substâncias psicoativas. Para isso, foram utilizados livros, teses de doutorado, dissertações de mestrado, artigos publicados em revistas acadêmicas, entre outros. Para tal, utilizou-se especialmente os seguintes descritores: (Substâncias psicoativas, fatores de adesão, Questão Social).

Os dados foram coletados e analisados segundo a análise de conteúdo de Bardin (2011) com o intuito de estabelecer correspondências entre as estruturas semânticas ou linguísticas (que estão na superfície do texto) e as estruturas psicológicas ou sociológicas (que determinam as características encontradas nos textos). Estas últimas se relacionam com a noção do contexto da mensagem, que possibilita o aprofundamento do significado, indo além das aparências.

Essa técnica baseia-se em operações de desmembramento do texto em unidade, ou seja, esta etapa visa a descobrir os diferentes núcleos de sentido que constituem a comunicação e, posteriormente, realizar o seu reagrupamento em categorias ou classes (BARDIN, 2011), o que aqui, originou cinco categorias: 1) Estigmas e preconceitos enfrentados por serem usuários de substâncias psicoativas; 2) motivação e busca por tratamento e problemas no início do processo de tratamento; 3) mudanças na qualidade de vida; 4) fatores que interferem no processo de adesão sob o olhar dos usuários; e 5) as possibilidades e os limites do trabalho do assistente social.

Nessa direção e considerando que o autor do trabalho esteve em lócus na prática profissional como estagiário, percebeu-se que os fatores de adesão eram situações que emergiram espontânea e contingencialmente na prática profissional e por isso se deu o anseio do pesquisador em realizar um aprofundamento teórico sobre o tema. Diante do exposto, acredita-se que investigar essa questão, compreendendo os aspectos que influenciam para a 
adesão sob a perspectiva dos próprios usuários é de extrema importância, pois segundo Moisés (2014) desconsiderar a fala do sujeito nos conduz a uma desconsideração de saberes fundamentais que o sujeito possui de si mesmo, do seu corpo, dos contextos de uso, que nos forneceriam pistas importantes para a condução dos tratamentos terapêuticos.

Este estudo pode propiciar a reflexão e estimular a revisão das estratégias de abordagem bem como a reorientação da prática profissional na área da Saúde, a partir da construção, produção e ampliação do conhecimento acerca dos fatores que interferem diretamente na adesão ao tratamento pelos usuários de substâncias psicoativas com vistas ao aumento da adesão e da qualidade de vida dessa população (FERREIRA et.al, 2015).

Dito isso, este trabalho está dividido em três capítulos. O primeiro pretende discorrer sobre a história da política de saúde, nuances da história da Saúde Mental e uma breve contextualização a respeito do uso de drogas explicitando de forma breve e geral como as especificidades do uso de substâncias psicoativas está circunscrita no cenário da Política Social e dos marcos da Seguridade Social. O segundo capítulo aborda o resgate histórico de forma breve a respeito do Serviço Social e o fenômeno do uso de drogas contextualizando com os determinantes sociais da saúde. Já o terceiro e último capítulo se direciona para a análise dos dados coletados por meio do grupo focal e buscará trazer subsídios com vistas a responder à questão da pesquisa. 


\section{CAPÍTULO 01: Política de Saúde, Saúde mental e Substâncias}

Psicoativas

"Algo muito ruim e que machuca é quando as pessoas nos chamam de drogados, vagabundos, mau caráter (usuário, 2018)". 


\title{
CAPÍTUlo o1 - Política de Saúde, Saúde mental e Substâncias Psicoativas
}

\section{1 - História da Política de Saúde e nuances da Política de Saúde mental}

Antes da criação do Sistema Único de Saúde (SUS) o Estado Brasileiro era ausente em relação à saúde da população. Na realidade, o que se imaginava era que o próprio indivíduo deveria cuidar da sua própria saúde e só havia intervenção estatal em casos graves que não pudessem ser solucionados pelo próprio sujeito ou que representasse um risco de epidemia a população ou um desequilíbrio na economia (PAIM, 2009).

Nesse sentido, antes da Constituição de 1988, no Brasil, a saúde não era considerada como um direito e só tinham acesso a ela os trabalhadores segurados pela previdência social, isto é, os indivíduos inseridos no mercado formal de trabalho e também os que possuíam recursos para pagar um plano de saúde privado (PAIM, 2009).

A camada da população em situação de pobreza e desigualdade, os trabalhadores domésticos e rurais, bem como todos os outros que não se encaixavam nesse perfil ficavam na dependência de obras assistenciais e das casas de misericórdia. A intervenção estatal em caráter universal se dava apenas nas campanhas de vacinação e de controle de endemias.

Paralelo a isso, e referente aos que necessitavam de cuidado em saúde, sobretudo de saúde mental, estavam aqueles que não seguiam um padrão de "normalidade", esquizofrênicos, mendigos e até mesmo os homossexuais. Segundo Mundim (2017), para isso, existiam os manicômios, isto é, locais de isolamento a esses grupos sociais. Em conformidade com a autora (2017):

\begin{abstract}
“[...] os pacientes não eram encaminhados para lá a fim de receberem um tratamento, mas sim para serem afastados da sociedade no qual eles não se encaixavam. Era uma sentença de reclusão e abandono, em que a única certeza era a da morte, que chegaria ali mesmo. Além disso, os doentes mentais eram tratados como animais, vivendo em condições desumanas, dormindo sobre capim sujo de fezes e urina. Se as medidas farmacológicas não fossem suficientes, a terapia de choque e a lobotomia eram feitas, sem qualquer aprovação das famílias, daqueles que ainda as tinham (Mundim, 2017, pg 03).
\end{abstract}

Nessa direção, a concepção de saúde hegemônica nessa época era centrada no modelo biomédico que dominante no mundo ocidental se concentrava na saúde puramente em termos biológicos desconsiderando os aspectos sociais, culturais, e econômicos dos indivíduos. Assim, segundo Melman (2006) entre as intervenções propostas dessa época, antes da Reforma Psiquiátrica, estava a normatização do comportamento, o controle do tempo, a

\footnotetext{
${ }^{6} \mathrm{O}$ conceito normalidade não existe, é um termo ultrapassado, por isso as aspas.
} 
rigidez de regras, o isolamento social, a consequente perda da identidade e da referência das pessoas segregadas. Essas práticas visavam reprogramar a existência dos sujeitos atendendo as exigências da ordem e da disciplina.

Além disso, e ainda sobre a omissão do Estado no âmbito da saúde brasileira, segundo Maria Inês Souza Bravo (2001), renomada autora do Serviço Social, a intervenção do Estado no âmbito da saúde como um todo se deu somente no século XX, mais efetivamente na década de 1930. No séc. XVIII, a assistência médica era pautada na filantropia e na prática liberal. No século XIX, em decorrência das transformações econômicas e políticas, algumas iniciativas surgiram no campo da saúde pública, como a vigilância do exercício profissional e a realização de campanhas limitadas.

Já nos últimos anos do século, a questão da saúde já aparece como reivindicação no nascente movimento operário e no início do séc. XX surgem algumas iniciativas de organização do setor saúde. Nessa direção, segundo Paim (2009).

Devido ao desenvolvimento do país e a concentração populacional nas grandes cidades, a saúde então aparecia como uma Questão Social. [...] a organização dos serviços de saúde no Brasil antes do SUS viviam em mundos separados: de um lado, as ações voltadas para a prevenção, o ambiente e a coletividade, conhecidas como saúde pública; de outro, a saúde do trabalhador, inserida no Ministério do Trabalho; e, ainda, as ações curativas e individuais, integrando a medicina previdenciária e as modalidades de assistência médica liberal filantrópica e, gradualmente, empresarial (PAIM, 2009).

Paim (2009) concorda com Braga e Paula, (1985) ao afirmarem que a Saúde emerge como Questão Social no Brasil no início do século XX, no bojo da economia capitalista exportadora cafeeira, refletindo o avanço da divisão do trabalho, isto é, a emergência do trabalho assalariado. (BRAGA \& PAULA, 1985).

Em decorrência da emergência da saúde como Questão Social, segundo Bravo (2001) as questões sociais em geral e as de saúde em particular, já colocadas na década de 1920, precisavam ser enfrentadas de forma mais sofisticada, e necessitavam transformarem-se em questão política, com a intervenção estatal e a criação de novos aparelhos que contemplassem de algum modo, os assalariados urbanos, que se caracterizavam como sujeitos sociais importantes no cenário político nacional, em consequência da nova dinâmica da acumulação.

Dessa maneira, a questão saúde vinha requerendo esforços cada vez mais sofisticados, pois o cuidado em saúde naquela época já não dava mais conta de todas as demandas da sociedade. Nesse sentido, a saúde, segundo a autora supracitada (2001) contou com a participação de novos sujeitos sociais na discussão das condições de vida da população 
brasileira e das propostas governamentais apresentadas para o setor, contribuindo para um amplo debate que permeou a sociedade civil.

Segundo Siqueira (2007), no Brasil, o cenário da saúde e da saúde mental passou a sofrer mudanças significativas na década de 1980, com o fim da ditadura militar e reabertura política do país para o regime democrático ${ }^{7}$. Esse período caracterizou-se pelo Movimento de Reforma Sanitária Brasileira $-\mathrm{MRSB}^{8}$ que resultou nas bases de construção do Sistema Único de Saúde - SUS e pelo Movimento de Trabalhadores de Saúde Mental - MTSM que contribuiu para a Reforma Psiquiátrica Brasileira - RPB.

Nessa direção, em conformidade com Bravo (2001), a sociedade brasileira nos anos de 1980, ao mesmo tempo em que vivenciou um processo de democratização política superando o regime ditatorial ${ }^{9}$ instaurado em 1964, e experimentando uma profunda e prolongada crise econômica que persiste até os dias atuais começou a discutir de forma mais contundente a questão da saúde. Segundo ela, as decepções com a transição democrática ocorreram, sobretudo, com seu giro conservador após 1988, não se traduzindo em ganhos materiais para a massa da população. (BRAVO, 2001)

À vista disso, conforme a autora supracitada (2001) após as iniciantes mobilizações sociais a respeito da questão saúde, esta deixou de ser interesse apenas dos técnicos para assumir uma dimensão política, estando estreitamente vinculada à democracia.

Sobre os atores sociais que entraram em cena nessa conjuntura, destacam-se: os profissionais de saúde, representados pelas suas entidades, que ultrapassaram o corporativismo, defendendo questões mais gerais como a melhoria da situação saúde e o fortalecimento do setor público; o movimento sanitário, tendo o Centro Brasileiro de Estudo de Saúde ${ }^{10}$ (CEBES) como veículo de difusão e ampliação do debate em torno da Saúde e da Democracia.

O MRSB nasceu no contexto da luta contra a ditadura ${ }^{11}$, no início da década de 1970 e sua expressão foi usada para se referir ao conjunto de ideias que se tinha em relação às

\footnotetext{
${ }^{7}$ Entendido como um sistema em que as pessoas de um país podem participar da vida política. Em uma democracia, as pessoas possuem liberdade de expressão e manifestações de suas opiniões.

${ }^{8}$ Esta categoria será discutida mais à frente.

${ }^{9} \mathrm{Em}$ termos gerais, compreende-se como um regime antidemocrático no qual não existe a participação da população.

${ }^{10} \mathrm{O}$ Centro Brasileiro de Estudos de Saúde é uma entidade nacional criada em 1976, cuja missão histórica é a luta pela democratização da sociedade e a defesa dos direitos sociais, em particular o direito universal à saúde.

${ }^{11} \mathrm{~A}$ ditadura foi o período da política brasileira em que militares conduziram o país. Essa época ficou marcada na história do Brasil através da prática de vários Atos Institucionais que colocavam em prática a censura, a perseguição política, a supressão de direitos constitucionais, a falta total de democracia e a repressão àqueles que eram contrários ao regime militar.
} 
mudanças e as transformações necessárias na área da saúde. Tais mudanças não abarcavam apenas o sistema, mas todo o setor saúde, em busca da melhoria das condições de vida da população.

Grupos de médicos e outros intelectuais preocupados com a saúde pública desenvolveram teses e integraram discussões políticas. Este processo teve como marco institucional a $8^{\text {a }}$ Conferência Nacional de Saúde, realizada em 1986 em Brasília, que explicaremos nos parágrafos à frente.

Conforme Bravo (2001), as principais propostas debatidas por esses sujeitos coletivos foram a universalização do acesso (de todos para todos); a concepção de saúde como direito social e dever do Estado; a reestruturação do setor por meio da estratégia do Sistema Unificado de Saúde visando um profundo reordenamento setorial com um novo olhar sobre a saúde individual e coletiva; a descentralização do processo decisório para as esferas estadual e municipal, o financiamento efetivo e a democratização do poder local por meio de novos mecanismos de gestão - os Conselhos de Saúde.

A autora (2001) salienta que um fato marcante e fundamental para a discussão da questão Saúde no Brasil, ocorreu na preparação e realização da $8^{a}$ Conferência Nacional de Saúde, realizada em março de 1986, em Brasília - Distrito Federal. O temário central versou sobre: A Saúde como direito inerente à personalidade e à cidadania; II Reformulação do Sistema Nacional de Saúde, III Financiamento setorial.

Paiva (2014), assim como Bravo (2001), sinaliza que a $8^{a}$ Conferência, numa articulação bem diversa das anteriores, contou com a participação de cerca de quatro mil e quinhentas pessoas, dentre as quais mil delegados. Representou, inegavelmente, um marco, com diversos avanços, pois introduziu no cenário da discussão da saúde a sociedade.

Segundo os autores, os debates saíram dos seus fóruns específicos ${ }^{12}$, ABRASCO, CEBES, Medicina Preventiva, Saúde Pública, e assumiram outra dimensão com a participação das entidades representativas da população: moradores, sindicatos, partidos políticos, associações de profissionais, parlamento. A questão da Saúde ultrapassou a análise setorial, referindo-se à sociedade como um todo, propondo-se não somente o Sistema Único, mas a Reforma Sanitária.

\footnotetext{
12 Para maiores informações a respeito dos fóruns específicos, ABRASCO, CEBES, Medicina Preventiva, Saúde Pública. Disponível em: < http://conselho.saude.gov.br/legislacao/3nob_sus.htm> Acesso em: 5. abril 2018.
} 
Dessa maneira, as propostas da Reforma Sanitária resultaram, finalmente, no acesso à saúde para todos, oficializado com a Constituição Federal de 1988 e a criação do Sistema Único de Saúde (SUS).

Paralelo a esses avanços, surgiram também alguns desdobramentos simultâneos a Reforma Sanitária Brasileira, dentre elas, as lutas sociais pela qualidade dos serviços de saúde mental.

Bisneto (2007) pontua que o início do Movimento de Reforma Psiquiátrica Brasileira se deu a partir dos modelos estrangeiros e quando muitos militantes das áreas de psiquiatria e psicologia alternativas aliaram-se ao Movimento dos Trabalhadores de Saúde Mental (MTSM) e organizaram diversos eventos para a discussão e reflexão das ideias que, na década de 1980 desencadearam o movimento.

Nessa direção, foi por volta de 1978 que o MTSM, movidos pela militância ideológica e política com referência nas reformas realizadas em outros países iniciaram um forte processo de questionamentos com relação às políticas de assistência psiquiátrica vigente na época, buscando uma Reforma Psiquiátrica.

Segundo a Coordenação Nacional de Saúde Mental e Drogas (2005) este movimento, por meio de variados campos de luta, passa a protagonizar e a construir, a partir deste período, a denúncia da violência dos manicômios, da mercantilização da loucura, da hegemonia de uma rede privada de assistência e a construir coletivamente uma crítica ao chamado saber psiquiátrico e ao modelo hospitalocêntrico na assistência às pessoas com transtornos mentais. (BRASIL, 2005)

Em conformidade com Amarante (1997) o MTSM torna-se o primeiro e mais importante ator de renovação no campo da saúde mental, estabeleceu uma agenda para o setor que, sob o título de Reforma Psiquiátrica, introduz a estratégia da Desinstitucionalização no âmbito das Políticas Públicas. Nesse sentido, as propostas no plano legal do movimento formalizaram a Reforma a partir dos anos 1980 - até os dias atuais -, em que as reivindicações foram feitas não só pelos trabalhadores do campo da saúde mental, mas, em especial, por associações dos próprios usuários dos serviços deste campo (OLIVEIRA e BARISON, 2008).

Assim, a Reforma Psiquiátrica é contemporânea ao movimento de Reforma Sanitária brasileira, no ano de 1980, e pretendia modificar o tratamento dado a pessoas com problemas de saúde, com vistas à "defesa da saúde coletiva, equidade na oferta dos serviços, e protagonismo dos trabalhadores e usuários dos serviços de saúde nos processos de gestão e produção de tecnologias de cuidado" (BRASIL, 2005). 
Dessa forma, o que se percebia antes do modelo proposto era uma segregação da população acometida por transtornos mentais, a partir de um processo de higienização das cidades e do isolamento dos sujeitos em casas especializadas.

Faz-se necessário salientar que no entendimento de Gonçalves e Sena (2001), a Reforma Psiquiátrica Brasileira teve como um dos seus principais eixos norteadores a desinstitucionalização e a consequente desconstrução do manicômio e dos pressupostos que o sustentam. Além de propor a assistência integral aos pacientes e designar que a internação em hospitais fosse o último recurso no tratamento das doenças mentais.

Os princípios da reforma psiquiátrica remetem à realidade social dos sujeitos em sofrimentos psíquico, pois as condições de vida de muitos desses sujeitos evidenciam todas as contradições que o modelo de reforma introduz, considerando a realidade sócia histórica desses sujeitos, os quais, embora algumas vezes libertos dos muros e das grades dos manicômios, encontram-se amarrados às estruturas sociais difíceis de serem quebradas. Estruturas estas decorrentes da realidade históricosocial das famílias, da comunidade, dos serviços públicos, da sociedade estabelecido e regente de todas as relações que se estabelecessem entre as pessoas. (RABELO, TAVARES \& FARIA 2009, p. 94).

Neste horizonte, as vozes das famílias e dos usuários dos serviços deixaram de ser apenas objeto de escuta qualificada passaram a ser vozes de cidadãos que passaram a contribuir no planejamento, na execução e na avaliação dos serviços prestados na política de saúde mental (TRABUCO e SANTOS, 2015).

Retomando ao contexto da Reforma Sanitária para a construção do SUS, segundo Souza \& Batista (2012), a primeira proposta do SUS foi apresentada pelo Centro Brasileiro de Estudos de Saúde (CEBES) no I Simpósio de Política Nacional de Saúde da Câmara dos Deputados no ano de 1979. Nove anos depois em 1988 foi promulgada a Constituição Federal, chamada Constituição Cidadã ${ }^{13}$, a qual contemplava os princípios e as diretrizes elaboradas pelo CEBES.

A proposta do SUS surge com uma nova definição de Saúde, reafirmando princípios da Organização Mundial da Saúde - OMS, de que a saúde não se trata apenas de ausência de doenças, mas considerando um aspecto mais ampliado que rompe com o domínio da medicina curativa apontando para a necessidade de reorganização dos modelos de atenção e promoção à saúde e a participação popular englobando políticas públicas de saneamento, moradia, alimentação, transporte, emprego e lazer.

\footnotetext{
${ }^{13} \mathrm{O}$ deputado e presidente da Assembleia Nacional Constituinte, Ulysses Guimarães, denominou a Carta de cidadã fazendo referência ao fato de que houve intensa participação popular na elaboração do texto porque quem quis se manifestou e foi acolhido. Chamada de constituição-cidadã por Guimarães, a Carta da República de 1988 é considerada até hoje uma das mais avançadas e democráticas do planeta, no que se refere aos direitos e garantias individuais do cidadão.
} 
Nesse sentido, a proposta do SUS foi materializada a partir do marco da Constituição Federal de 1988 (BRASIL, 1988), quando o Brasil começou a presenciar mudanças significativas em todos os contextos, nos âmbitos político, social e econômico. $\mathrm{O}$ referido marco rompeu com os padrões que, até então, estavam em evidência e engendrou a concepção de Seguridade Social: Art. 194. A Seguridade Social compreende um conjunto integrado de ações de iniciativa dos poderes públicos e da sociedade, destinadas a assegurar os direitos relativos à saúde, à previdência e à assistência social.

Como fundamentos da concepção de Seguridade Social tem-se: a concepção de direito social e de dever do Estado; a melhoria da qualidade dos serviços; a determinação da origem de financiamento e a gestão democrática com destaque na participação social.

Esses fundamentos surgiram como proposta da Reforma Sanitária Brasileira (RFB), o que acabou constituindo uma nova organização de Saúde que atualmente se conhece como SUS, que segue em consonância com os princípios de descentralização, universalização, participação social, integralidade, intersetorialidade, e um efetivo financiamento do Estado, além, é claro, de uma redefinição dos papéis institucionais das unidades políticas (União, Estado, Municípios e Territórios) na prestação dos serviços de saúde.

Nessa direção, segundo Boschetti (2006), um dos pilares de estruturação da Seguridade Social é sua organização com base na lógica do seguro social, e seus princípios apesar de estarem formalizados na Lei não foram respeitados em sua totalidade. Segundo ela, a Seguridade Social no Brasil agregou universalidade e seletividade, centralização e descentralização, distributividade e redistributividade, gratuidade e contributividade, o que segundo a autora acabou se caracterizando como um sistema híbrido.

Por outro lado, segundo Silva (2018) apesar dos evidentes avanços no reconhecimento dos direitos sociais e na regulamentação da Seguridade Social, há diversas críticas, como a de Pereira (1993), que considera que o sistema de Seguridade Social brasileiro se estruturou de maneira restrita e acanhada.

Segundo Pereira (2002), a Constituição Federal de 1988 introduziu avanços significativos no ordenamento legal brasileiro ampliando direitos e corrigindo iniquidades. Tais avanços tiveram particular relevância no âmbito da Seguridade Social, um conceito até então ausente na legislação e na experiência nacionais de proteção pública.

Nessa perspectiva, a saúde enquanto direito de todos e dever do Estado foi formalizada na Seguridade Social: 
universal e igualitário às ações e serviços para sua promoção, proteção e recuperação (BRASIL, 1988)

Constituindo-se como uma política inovadora, na qual o direito ao acesso torna-se universal, igualitário e gratuito e se configuram como um aprofundamento e a afirmação dos direitos sociais de acordo com as modificações sociopolíticas que se procederam.

Vale destacar que embora o SUS esteja formalizado desde a Constituição Cidadã foi somente no ano de 1990 que se deu a efetivação e a regulação do Sistema, com a promulgação das Leis 8.080/90 e da Lei 8.142/90, com a primeira referindo-se à promoção da saúde e à organização dos serviços e a segunda, à participação da comunidade e ao repasse de recursos do governo federal para as demais instâncias.

Referente ao funcionamento, é importante observar que o SUS não dispõe de um caráter institucional. Ele é um complexo sistema, formado por centros de saúde, ambulatórios, laboratórios, hospitais da iniciativa privada e do poder público, bem como por outros órgãos da União, dos Estados e dos Municípios, tendo como gestor central o Ministério da Saúde, todavia participam também da sua gestão, os Estados, os Municípios e a comunidade.

Portanto, pode-se definir o SUS como um conjunto de ações e de serviços públicos de saúde, compondo uma rede regionalizada e hierarquizada, organizada a partir das diretrizes da descentralização, da integralidade e da participação da comunidade. Sendo assim, uma forma de organizar as ações e os serviços de saúde no Brasil, de acordo com os princípios, diretrizes e dispositivos estabelecidas pela Constituição da República e pelas leis subsequentes, como por exemplo, as leis 8.080/90 e 8.142/90 (PAIM, 2009).

Como princípios norteadores do SUS destacam-se: a saúde como direito de todos e dever do Estado; preservação da autonomia das pessoas na defesa de sua integridade física e moral; direito à informação sobre saúde; igualdade de assistência à saúde, sem preconceitos ou privilégios de qualquer espécie; participação da comunidade, dentre outros (BRASIL, 1990).

Ainda no que se refere ao SUS, a rede de atenção está dividida em três níveis de complexidade: básica, média e alta. No nível básico de complexidade, insere-se o primeiro nível de atenção à saúde e orienta-se pelos mesmos princípios gerais do SUS, mas com tecnologias de baixa densidade. A principal estratégia utilizada para a organização da rede de atenção básica materializa-se por meio da Estratégia de Saúde da Família - ESF ${ }^{14}$ (BRASIL, 2007).

\footnotetext{
${ }^{14}$ De acordo com o Ministério da Saúde, a Estratégia Saúde da Família (ESF) busca promover a qualidade de vida da população brasileira e intervir nos fatores que colocam a saúde em risco, como falta de atividade física,
} 
Como média complexidade, são consideradas as ações e os serviços que objetivam atender aos principais problemas de saúde da população, cuja complexidade da assistência na prática clínica necessite de profissionais especializados e de recursos tecnológicos, para o apoio diagnóstico e o tratamento (BRASIL, 2007).

Além disso, os serviços de especialidade e a atenção hospitalar de média complexidade tornaram-se, frequentemente, a verdadeira porta de entrada do sistema, atendendo diretamente grande parte da demanda que deveria ser atendida na rede básica, perdendo-se tanto a qualidade no atendimento primário quanto no acesso da população aos tratamentos especializados (quando verdadeiramente necessários), representando, além disso, ampliação ineficiente dos gastos do SUS (BRASIL, 2007).

Por outro lado, no atendimento de alta complexidade encontram-se os serviços com maior investimento tecnológico, propiciando à população acesso aos serviços de maior qualidade, sendo que se integram aos demais níveis de atenção descritos anteriormente (BRASIL, 2009).

Diante do exposto, é possível inferir que, segundo Elias (2004) o SUS representou uma importantíssima vitória do movimento pela Reforma Sanitária, mas ainda busca se consolidar como política de Estado ancorada em bases sociais sólidas, segundo o autor, avanços significativos foram alcançados, apesar das ameaças que se estabelecem com as privatizações da assistência em saúde.

Como salientam os teóricos da temática SUS, faz-se necessária a elaboração de leis complementares e ordinárias para detalhar e disciplinar princípios e diretrizes constitucionais, abrindo-se a possibilidade de constantes diálogos entre equipes, governo e sociedade na construção de políticas públicas que atendam aos anseios e às necessidades reais da população (NASCIMENTO et.al 2013)

Como se vê, dentre as várias políticas no âmbito do SUS tem-se a Política de Saúde Mental que, a partir da Reforma Psiquiátrica apresentou outro modelo de atenção e foram inseridos na Política de Saúde, como também seus mecanismos de implantação. Assim, no próximo tópico abordaremos as implicações do uso de substâncias psicoativas para a saúde mental.

\subsection{AS IMPLICAÇÕES DAS SUBSTÂNCIAS PSICOATIVAS NA SAÚDE MENTAL}

má alimentação e o uso de tabaco. Com atenção integral, equânime e contínua, a ESF se fortalece como uma porta de entrada do Sistema Único de Saúde (SUS). 
A Lei n. 10.216/2001, sancionada em 6 de abril de 2001 direciona e redireciona a Atenção à Saúde Mental, que regulamenta a não internação dos indivíduos que têm transtorno mental; consiste também em um novo modelo de assistência psiquiátrica na interação social do usuário com transtorno mental, bem como a implantação de Residências Terapêuticas e Centros de Atenção Psicossocial (CAPS) e direitos colocado pelo Estado para os usuários com transtorno mental (VASCONCELOS, 2008).

Os CAPS têm como função promover a inserção social das pessoas com transtornos mentais, por meio de ações intersetoriais e regulares a porta de entrada da rede de assistência em saúde mental na sua área de atuação, dando suporte à atenção em saúde mental na rede básica.

Em conformidade com Scheffer \& Silva (2014) a transformação dos Serviços de Saúde Mental rompe com fatores vivenciados pelos usuários, historicamente cruéis e desumanos. A visão do tratamento com os usuários hoje é intensa e aberta, sem precisar de regime asilar e injusto.

A nova concepção de saúde mental, que visa priorizar o indivíduo e não a doença, oferecendo-lhe tratamento humanizado e de qualidade, resultou na criação de novos mecanismos e espaços de tratamento que provocam para a necessidade de uma ação intersetorial com as demais políticas sociais e de um trabalho pautado no fortalecimento e atuação em rede, que possibilite uma intervenção integrada, visando à integralidade no atendimento ao usuário. (BREDOW e DRAVANZ, 2010, p. 232)

Vale a pena reforçar que o movimento da Reforma Psiquiátrica Brasileira se apresentou como a ruptura do então modelo proposto no âmbito da Saúde Mental, fazendo com que o usuário do serviço não fosse visto mais como "louco" 15 , institucionalizado e sem perspectivas de recuperação e melhora na qualidade de vida. (BANDEIRA, 2014)

Segundo Scheffer \& Silva (2014) a Reforma Psiquiátrica está alicerçada no Sistema Único de Saúde (SUS), tendo como seus princípios norteadores ${ }^{16}$ : saúde, como um direito fundamental e dever do Estado, enfatizando o acesso universal na atenção em saúde mental com base em integralidade, intersetorialidade, equidade, universalidade, igualdade e no controle social. Salienta-se, porém, que a Reforma Psiquiátrica não está acabada e continua sendo uma luta constante até os dias de hoje.

Referente ao processo de trabalho em saúde mental vale a pena notabilizar que este está pautado em uma concepção ampliada de saúde com base no SUS, implicada numa relação com o contexto econômico, social e cultural do país; ou seja, abrange situações de

\footnotetext{
${ }^{15}$ Destaque do autor

${ }^{16}$ Para maiores esclarecimentos acerca dos princípios, consultar: Carta dos direitos dos usuários da saúde / Ministério da Saúde. - 3. ed. - Brasília: Ministério da Saúde, 2011.
} 
moradia, saneamento, renda, alimentação, educação, acesso ao lazer e bens. Essa nova concepção busca abrir canais de democratização dos saberes profissionais, bem como das informações acerca do processo de saúde/sofrimento psíquico (MACHADO, 2009).

Dito isso, destaca-se que, dentre os diversos pacientes que são atendidos no âmbito da Saúde Mental, tem-se também os usuários de substâncias psicoativas que necessitam de uma assistência integral e que, quando dependentes de tais substâncias são considerados com uma doença mental. Conforme a Organização Mundial da Saúde (OMS, 2011) a dependência química é definida como uma doença crônica, progressiva, isto é, que piora com o passar do tempo.

A instituição alerta que a dependência química é um transtorno mental caracterizado por um grupo de sinais e sintomas decorrentes do uso de drogas. Esses sinais e sintomas são: compulsão pelo uso da droga; sintomas de abstinência, necessidade de doses crescentes para atingir o mesmo efeito; falta de controle sobre a quantidade do uso; abandono de outras atividades e manutenção do uso, mesmo tendo prejuízos evidentes causados pelas substâncias psicoativas.

Nessa direção, no Relatório Mundial sobre Drogas de 2015, o Escritório das Nações Unidas sobre Drogas e Crimes (UNODC) destaca que cerca de 246 milhões de pessoas, ou um pouco mais de 5\% da população mundial entre 15 e 64 anos de idade, usaram drogas ilícitas em 2013. Usuários de drogas problemáticos somaram por volta de 27 milhões, das quais quase metade são pessoas que fazem uso de drogas injetáveis. Só no Brasil, o índice é de mais ou menos 6 milhões de brasileiros dependentes químicos, o equivalente a 3\% da população geral.

Considerado a problemática do uso de drogas, segundo a autora do Serviço Social, Woerner, (2015), o Brasil passou a ter uma rede de serviços disponível para o atendimento de abusadores e de dependentes químicos, contando com ações por parte da política de assistência social, poder Judiciário, serviços de cunho privado, entidades filantrópicas e religiosas e ações desenvolvidas também pelo Sistema Único de Saúde - SUS.

Ainda segundo a referida autora, tais ações são reguladas por meio da Política de Saúde, pelo SUS, regulamentadas pela Portaria $\mathrm{n}^{\circ} 3.088$, de 23 de dezembro de 2011, que “Institui a Rede de Atenção Psicossocial para pessoas com sofrimento ou transtorno mental e com necessidades decorrentes do uso de crack, álcool e outras drogas no âmbito do Sistema Único de Saúde" (BRASIL, 2011). Dessa forma, os serviços passam a ser organizados de forma que o CAPS - Centro de Atenção Psicossocial - torne-se responsável, de forma primordial, a prestar o atendimento a essa população. 
Considera-se que, no caso de usuários de drogas, a porta de entrada do sistema é por meio dos CAPS dos municípios, contudo, em alguns casos podem ocorrer equívocos, sendo diretamente o ambiente hospitalar o primeiro espaço a ser procurado, ao contrário do previsto na legislação.

A Política Nacional de Saúde Mental nesse campo engloba as estratégias e diretrizes adotadas pelo país com a finalidade de organizar a assistência às pessoas com necessidades de tratamento e cuidados específicos em Saúde Mental. Abrange a atenção a pessoas com necessidades associadas a transtornos mentais como a depressão, a ansiedade, a esquizofrenia, o transtorno afetivo bipolar, o transtorno obsessivo-compulsivo, inclusive aquelas com quadro de uso nocivo e de dependência de substâncias psicoativas (Álcool, cocaína, crack e outras drogas).

De acordo com o Ministério da Saúde (2017), como diretrizes do Sistema, o SUS dispõe-se da implantação de uma Rede de Serviços aos usuários que seja plural, com diferentes graus de complexidade e que promovam assistência integral para diferentes demandas, desde as mais simples às mais complexo-graves. As abordagens e condutas devem ser baseadas em evidências científicas.

Segundo o Portal do Ministério da Saúde (2017), para expandir e qualificar a RAPS, foi destinado pelo governo federal um adicional de mais de $\mathrm{R} \$ 320$ milhões por ano, totalizando R \$ 1,6 bilhão. A RAPS foi ampliada e passa a contar com hospitais psiquiátricos especializados, hospitais-dia, unidades ambulatoriais e CAPS IV AD, além dos antigos serviços já existentes, com o objetivo de ofertar uma variedade de cuidados, que possam dar conta das diferentes necessidades dos pacientes. As ações foram construídas conjuntamente entre os gestores do SUS e cerca de 70 entidades, todas conhecedoras da realidade da saúde mental no país.

A Rede de Atenção Psicossocial (RAPS) passa a ser formada pelos seguintes pontos de atenção (Serviços):

- CAPS (Centro de Atenção Psicossocial), em suas diferentes modalidades;

- Serviço Residencial Terapêutico (SRT);

- Unidade de Acolhimento (Adultos e infanto-juvenis);

- Enfermarias Especializadas em Hospital Geral;

- Hospital Psiquiátrico;

- Hospital-Dia;

- Atenção Básica; 
- Urgência e Emergência;

- Comunidades Terapêuticas;

- Ambulatório Multiprofissional de Saúde Mental.

No entanto, e considerando tudo que foi dito a respeito do SUS e dos serviços disponibilizados na Rede, bem como as políticas brasileiras referentes sobre o uso/abuso/dependência de drogas, relacionadas no âmbito da Saúde Mental é possível depreender que embora elas sejam bastante amplas e bem caracterizadas formalmente no ordenamento jurídico, no momento da materialização é permeada por muitos desafios que dificultam sua concretização, desafios estes que são tanto de ordem econômica quanto política e financeira.

Sobre isso, segundo Backes et.al (2014) para sanar alguns equívocos em relação à materialização do SUS é preciso transcender o pensamento simplificador e linear de apreender o SUS e conceber um pensar complexo, capaz de integrar e interligar os diferentes saberes, serviços e setores de saúde.

Assim, ainda em conformidade com os autores (2014) a educação permanente em saúde se apresenta como um dispositivo dinamizador de posturas profissionais mais afirmativas em relação ao desenvolvimento do SUS. O envolvimento dos usuários, a partir da apropriação da proposta que orienta esse sistema, bem como dos seus direitos e deveres, também se mostra como elemento com potencial retroativo para novas formas de analisá-lo, dinamizá-lo e gerenciá-lo.

Paralelo a isso, faz-se necessário destacar a Política Nacional de Humanização (PNH) que lançada em 2003, busca pôr em prática os princípios do SUS no cotidiano dos serviços de saúde, produzindo mudanças nos modos de gerir e cuidar. Nesse escopo, referente aos usuários de álcool e outras drogas, esses princípios são de extrema importância para consolidar os objetivos da reforma psiquiátrica e a humanização ao atendimento dessa população.

A PNH estimula a comunicação entre gestores, trabalhadores e usuários para construir processos coletivos de enfrentamento de relações de poder que muitas vezes produzem atitudes e práticas desumanizadoras que inibem a autonomia e a corresponsabilidade dos profissionais de saúde em seu trabalho e dos usuários no cuidado de si.

Como diretrizes, a Política Nacional de Humanização a partir de orientações clínicas, éticas e políticas, que se traduzem em determinados arranjos de trabalho: a gestão participativa e cogestão, ambiência; clínica ampliada e compartilhada, valorização do 
trabalhador, defesa dos direitos dos usuários e acolhimento. Este último indispensável em todo o processo de trabalho dos profissionais de saúde na relação com os usuários, sobretudo, aos que estão relacionados com a problemática de uso/abuso de substâncias psicoativas.

Segundo a PNH (2003) acolher é reconhecer o que o outro traz como legítima e singular necessidade de saúde. O acolhimento deve comparecer e sustentar a relação entre equipes/serviços e usuários/ populações. Como valor das práticas de saúde, o acolhimento é construído de forma coletiva, a partir da análise dos processos de trabalho e tem como objetivo a construção de relações de confiança, compromisso e vínculo entre as equipes/serviços, trabalhador/equipes e usuário com sua rede sócia afetiva.

Além disso, e ainda em conformidade com a política supramencionada (2003), com os trabalhadores pautados em uma escuta qualificada oferecida às necessidades do usuário, é possível garantir o acesso oportuno desses usuários a tecnologias adequadas às suas necessidades, ampliando a efetividade das práticas de saúde. Isso assegura, por exemplo, que todos sejam atendidos com prioridades a partir da situação social, gravidade e risco. (HUMANIZA SUS, 2003).

Nesse movimento, é sabido que os usuários de drogas e dependentes de álcool podem ser vítimas do sistema capitalista, de diversas formas, e não são problemas isolados de tal. Sobre isso, Siqueira argumenta que: (2007).

O sistema capitalista dominante não garante as condições que atendam as reais necessidades sociais e atinge as maneiras de pensar, ser e agir em sociedade. No setor saúde mental, os pacientes com transtornos mentais além de enfrentar a fome, a falta de moradia, trabalho, alimentação, lazer, condições necessárias à saúde integral, enfrentam o preconceito, a discriminação, o medo, o estresse, a banalização dos problemas sociais, como a própria doença mental (SIQUEIRA, 2007).

Concorda-se com o argumento da autora e acrescenta-se que a questão é que eles não devem ser limitados ao vício e meramente serem vistos como vítimas, marginalizados e reconhecidos pelos estigmas. É importante salientar que existem sujeitos por trás do vício, da dependência do álcool e outras drogas e que tiveram motivações para estarem onde estão e que hoje precisam de apoio, e serem compreendidos como sujeitos de direitos, seja pelos CAPS, pelas políticas de Redução de Danos, e também pela sociedade. Faz-se necessário destacar que a condição de sujeito de direitos não pode ser anulada, reduzida ou ignorada em decorrência do uso de substâncias psicoativas, independentemente do caráter lícito ou ilícito da substância consumida.

Em suma, é notório que há um longo caminho para ser percorrido, no que se refere aos avanços e à implementação de políticas de Saúde Mental, álcool e outras drogas. 
Contudo, o importante é que os passos estão sendo dados. Partindo-se do princípio de que tudo faz parte de um processo histórico, isto é, dialético, e que as mudanças não se fazem da noite para o dia, acredita-se na esperança de ver tais mudanças sendo materializadas na prática da vida cotidiana. 
CAPÍTULO 2: Uso de Substâncias Psicoativas e o Serviço Social: Conceitos e Determinantes Sociais de Saúde

Minha vida mudou muito, aprendi a me cuidar mais, as vezes poderia até tá morto continuando na vida que eu estava" (usuário, 2018) 


\title{
CAPÍTULO 2- Uso de Substâncias Psicoativas e o Serviço Social: Conceitos e Determinantes Sociais de Saúde
}

\subsection{Uso de Álcool e outras drogas e seus conceitos}

O uso de drogas na história da humanidade é uma prática milenar e universal, como pode-se observar na fala de Sollero (1979):

\begin{abstract}
Procurou o homem, desde a mais remota antiguidade, encontrar um remédio que tivesse a propriedade de aliviar suas dores, serenar suas paixões, trazer-lhe alegria, livrá-lo de angústias, do medo ou que lhe desse o privilégio de prever o futuro, que lhe proporcionasse coragem, ânimo para enfrentar as tristezas e o vazio da vida. (SOLLERO, 1979, p. 39).
\end{abstract}

Nesse sentido, o homem, nas diversas culturas, sociedades e épocas sempre consumiu drogas, o que, na maioria das vezes, não se concebeu em problemas e motivos para alarmes sociais. Elas eram consumidas com fins religiosos, terapêuticos e lúdicos, entendidas como uma manifestação cultural e humana (BRASIL, 1999). O café, as bebidas alcoólicas, a cocaína, o rapé são substâncias que segundo Bastos e Cotrim (1998), estiveram e ainda estão presentes nas cerimônias religiosas e em medicamentos caseiros, dentre outros.

Nessa direção, existe uma relação histórica dos homens e das mulheres com as drogas, pois não existiu sociedade que não se tenha registros do uso de alguma substância psicoativa. Logo, o uso de drogas e seus significados são produtos da práxis social ${ }^{17}$ historicamente construída: sejam os usos terapêuticos, os rituais ou os alimentares das sociedades tradicionais, seja os usos hedonistas ou dependentes, atualmente presentes na sociedade capitalista tardia (BRITES, 2006).

Ao longo da história da sociedade, muitas demandas foram postas à atuação profissional do assistente social, as então denominadas expressões da Questão Social, entendidas como o "conjunto das expressões das desigualdades da sociedade capitalista" (IAMAMOTO, 1999, p. 27).

Nessa perspectiva, contemporaneamente, segundo a autora Woerner (2015), o uso e abuso de drogas, aqui denominadas substâncias psicoativas (SPA), tem se constituído enquanto uma expressão da Questão Social, sendo considerada uma problemática de Saúde Pública. De acordo com a autora, o trabalho do assistente social também contempla a atuação junto a dependentes químicos, assim denominados aqueles que fazem uso abusivo de substâncias psicoativas e de seus familiares. Essa intervenção é materializada em distintos

\footnotetext{
${ }^{17}$ A práxis dos seres humanos é previamente determinada de forma consciente, é justamente isso que diferencia a práxis humana. O homem cria suas próprias necessidades, mesmo a necessidade de alimentação é socialmente condicionada no homem. (VASQUES, 2007)
} 
espaços sócio ocupacional e a modalidades de atendimento, sendo os profissionais requisitados a intervir em tais situações.

Nessa lógica, Crives \& Dimenstein (2003) sinalizam que, nas últimas décadas, indicadores apontam que o consumo alarmante tem tomado dimensões preocupantes, tendo graves consequências, sobretudo para os jovens e adultos, materializando-se- nos vários aspectos da vida cotidiana, como por exemplo, em relação à família, comprometendo vínculos afetivos, no trabalho, no trânsito, na saúde, e inclusive, na disseminação do vírus HIV (BRASIL, 1999).

De acordo com Bastos e Cotrim (1998) incontáveis são os danos secundários ao consumo abusivo de substâncias psicoativas, a saber: acidentes de trânsito, overdoses, envenenamentos, doenças cardiorrespiratórias e a violência resultante da ação farmacológica das drogas, como: brigas, homicídios, furtos e roubos, etc.

Além desses, muitos são os danos sociais relacionados à Saúde Mental que com o uso de substâncias psicoativas acentuam mais ainda a gravidade, tais como a depressão, a ansiedade, e outros transtornos mentais, sem contar as alterações significativas de percepção, de pensamento e de humor. Estudos revelam que cerca de uma em cada cinco pessoas que faz uso de drogas ilícitas possui critério para diagnóstico de dependência, e essas substâncias afetam a percepção, o humor e a consciência de seus usuários, o que pode reduzir e/ou influenciar a capacidade dos usuários em exercer o controle sobre o uso de drogas.

Dessa maneira, com as implicações e uma profunda incapacidade e perda da Saúde Física, as pessoas com transtornos causados pelo uso de álcool e outras drogas podem sofrer gravemente com problemas psicológicos e psicossociais, problemas interpessoais, perda de emprego, dificuldades cognitivas, bem como problemas com a justiça.

Considerando a temática do uso de drogas, é fundamental esclarecer as diferenças que existem entre o uso, o abuso e a dependência de SPA's. Todavia, tais diferenças apresentam-se em uma linha tênue, uma vez que o término de uma e início de outra não são evidentemente definidos, bem como a passagem entre tais estágios não ocorre de forma linear. Assim sendo, efetivar a identificação do uso problemático de SPAs se institui uma tarefa ainda controversa, sobretudo com relação à definição do que se estabelece como normalidade e "anormalidade" 18 do uso (PECHANSKY et al, 2004).

Nesse sentido, segundo a OMS, os principais padrões de uso de substâncias psicoativas, são o uso, o abuso e a dependência. De maneira sintética pode-se entender o

${ }^{18}$ Destaque do autor 
estágio de uso como a utilização esporádica de algum tipo de SPA, o abuso como um uso que acaba por acarretar algum tipo de prejuízo, e a dependência encontra-se associada ao surgimento de vários problemas, bem como a ausência de controle sobre o uso.

$\mathrm{Na}$ atualidade, a dependência de substâncias psicoativas é diagnosticada tomando como base os critérios definidos na Classificação Internacional de Doenças - CID (OMS, 1993) e no Manual Diagnóstico e Estatístico de Transtornos Mentais (DSM, Diagnostic and Statistical Manual of Mental Disorders 1952) (AMERICAN PSYCHIATRIC ASSOCIATION, 2013) adquirindo, dessa forma, status de doença propriamente dita. Os autores Edwars e Gross (1999) utilizam elementos-chave para caracterizar a síndrome da dependência, sendo eles: Estreitamento do repertório, a saliência do uso, o aumento da tolerância, os sintomas de abstinência, o alívio ou evitação dos sintomas, a percepção subjetiva da compulsão para o uso e a reinstalação após a abstinência.

Estudos do UNODC ano de 2014 mostram que cerca de 243 milhões de pessoas, número que se equipara a 5\% da população, faz o uso de substâncias psicoativas ilícitas e, destes, $0,6 \%$ desenvolvem a dependência de tais substâncias, causando intenso abalo na vida individual, familiar, social e ocupacional. Três anos depois, segundo o Relatório Mundial sobre Drogas de 2017, é evidenciado que cerca de 250 milhões de pessoas usaram drogas no ano de 2015 (UNODC, 2017)

Desta forma, é evidente que o fenômeno do uso, do abuso e da dependência de substâncias psicoativas tem tomado proporções cada vez maiores, acarretando consequências adversas em escala individual e coletiva. Os reflexos de tal realidade são percebidos na esfera da Saúde, da Segurança Pública e as preocupações se ampliam nas questões concernentes ao tráfico de drogas e à violência em seus diversos aspectos.

À vista disso, os impactos de tal fenômeno não ficam restritos ao indivíduo que faz o uso da substância propriamente dita, mas são excedidos para o escopo familiar e comunitário, constituindo-se como preocupação e foco de ação de diversas políticas públicas e demais setores da sociedade civil.

Por muito tempo, no Brasil, o uso de substâncias psicoativas foi encarado somente sob o prisma da segurança pública e, só no séc. XX, devido aos diversos impactos na vida social, política e econômica, que se tornou uma questão de saúde pública. Segundo o relatório de "Gestão 2003-2006: Saúde mental no SUS: acesso ao tratamento e mudança do modelo de atenção", a saúde pública brasileira não vinha se ocupando devidamente do grave problema da prevenção e do tratamento de transtornos associados ao consumo de álcool e outras drogas, produzindo historicamente uma importante lacuna na política pública de saúde, deixando-se a 
questão das drogas para as instituições da justiça, segurança pública, pedagogia, benemerência, associações religiosas.

A complexidade da problemática cooperou para a relativa ausência do Estado, e possibilitou a disseminação em todo o país de alternativas de atenção de caráter total, fechado, baseadas em práticas predominantemente medicamentosa, disciplinar, proibicionista ou, ainda, de cunho religioso, tendo como objetivo quase exclusivo a ser alcançada a abstinência. Muitos estudiosos do assunto (ACSERALD, 2003; TIBA, 1999; SUDBRACK et al, 2003) advertem que as políticas antidrogas precisam romper com a perspectiva exclusivamente repressiva e investir categoricamente em ações preventivas. São harmônicos em afirmar que a repressão por si só, não é capaz de prevenir o uso indevido de drogas. Pois como é sabido, o uso de drogas é uma prática que ultrapassa as condições de decisão e de escolha dos sujeitos.

De acordo com os vários teóricos do assunto (ACSERALD, 2003; TIBA, 1999; SUDBRACK et al, 2003), o consumo pode ser feito de forma ocasional, sem nenhuma determinação orgânica, porém também pode ocorrer por determinação orgânica. Nesta última, as pessoas consomem drogas pela existência de dependência físico-química e psíquica, isto é, o consumo de drogas é uma doença.

Segundo Silva (2007), os efeitos negativos consequentes do uso de drogas fizeram com que fosse construída paulatinamente e no interior do Estado Brasileiro uma tendência de enfrentamento a essa problemática. No início, prevaleceu a perspectiva de repressão. Nos meados dos anos 1990, surgiu outra proposta defendida por estudiosos que criticavam a repressão: a perspectiva da prevenção e do tratamento.

Essa proposta, de acordo com a supracitada autora (2007) rompeu com a tendência repressiva e incluiu a temática das drogas no centro do debate das políticas públicas, como uma expressão da Questão Social. Deste modo, a questão das drogas foi inserida na agenda pública passando a constituir-se como uma construção coletiva, que deveria envolver os sujeitos em todas as suas relações sociais: na família, na vizinhança, nos grupos de amigos, de trabalho, na escola, isto é, em todos os espaços sociais.

Nesse sentido, no ano de 2006, o Brasil instituiu a Lei ${ }^{\circ}$ 11.343/2006 que estabelece a necessidade do acompanhamento psicossocial ao usuário de substâncias psicoativas, oportunizando a reflexão do mesmo sobre a sua prática ao invés da privação de liberdade, sendo aplicadas penas alternativas ao dependente/usuário e não medidas de encarceramento (BRASIL, 2006). 
A Lei $n^{\circ} 11.343 / 2006$ foi aprovada e instituiu o Sistema Nacional de Políticas Públicas sobre Drogas (SISNAD) ${ }^{19}$, inserindo o Brasil em evidência no cenário internacional ao instituir o SISNAD, passou a prescrever medidas para prevenção do uso indevido, atenção e reinserção social de usuários e dependentes de drogas, em consonância com a atual política sobre drogas. Esta lei procura harmonizar os dois mecanismos normativos: as Leis $\mathrm{n}^{\circ}$ 6.368/1976 e 10.409/2002, e os anula a partir de sua promulgação, com o reconhecimento das diferenças entre a figura do traficante e a do usuário/dependente, os quais passaram a ser tratados de modo diferenciado e a ocupar capítulos diferentes da lei.

O Estado Brasileiro entendeu que a questão das drogas é complexa e que não deveria ser entendida somente sob o prisma judicial, nesse sentido, compreendeu que os usuários e dependentes de substâncias psicoativas não poderiam ser penalizados pela justiça com a privação de liberdade. Isto posta, a justiça retributiva fundamentada no castigo é deslocada pela justiça restaurativa, cujo propósito maior é a ressocialização por meio de penas alternativas:

1. Advertência sobre os efeitos das drogas;

2. Prestação de serviço à comunidade em locais/programas que se ocupem da prevenção/recuperação de usuários e dependentes de drogas;

3. Medida educativa de comparecimento à programa ou curso educativo.

Além do mais, existem, atualmente, duas políticas públicas para as questões relacionadas ao consumo de álcool e outras drogas: uma elaborada pelo Ministério da Saúde, de Atenção aos Usuários de Álcool e outras Drogas, e outra, aprovada pelo Conselho Nacional Antidrogas da Secretaria Nacional de Políticas sobre Drogas - SENAD.

Segundo a Política de Atenção Integral aos usuários de Álcool e Outras Drogas, são práticas que devem ser obrigatoriamente consideradas em uma perspectiva ampliada de saúde pública: proporcionar tratamento na atenção primária; garantir o acesso a medicamentos, garantir atenção na comunidade; fornecer educação em saúde para a população, envolver comunidades /famílias /usuários; formar recursos humanos, criar vínculos com outros setores, monitorizar a saúde mental na comunidade, dar mais apoio à pesquisa e estabelecer programas.

No âmbito desta mesma política, no Brasil, é notório que o tema tem sido tratado de modo pontual, contando com esforços de setores e grupos preocupados com o aumento

\footnotetext{
${ }^{19}$ Para maiores esclarecimentos, disponível em: https://obid.senad.gov.br/nova-arquitetura/a-politica-sobredrogas-no-brasil/legislacao/sistema-nacional-de-politicas-publicas-sobre-drogas-sisnad> Acesso em: 06.mar.2019.
} 
exponencial do problema do uso abusivo de álcool e outras drogas. O Ministério da Saúde assume de modo integral e articulado o desafio de prevenir, tratar, reabilitar os usuários de álcool e outras drogas como um problema de saúde pública (BRASIL, 2003). Esta deliberação responde às propostas que foram destacadamente recomendadas pela III Conferência Nacional de Saúde Mental, em dezembro de 2001 (III CNSM, Relatório Final, 2001).

Conforme Vargas \& Oliveira (2012) embora as reformas na saúde, educação ou previdência social anunciadas no mundo pós-moderno sejam, na maioria das vezes, para piorar a vida dos cidadãos, há de se ponderar que, teoricamente, a Política Nacional para a Atenção aos Usuários de Álcool e outras Drogas, do Ministério da Saúde, concorre para a emancipação social dessas pessoas, uma vez que propõe estratégias que promovem o cuidado, a autonomia, a reabilitação psicossocial e a inclusão social pelo trabalho, uma vez que as pessoas se reconhecem como cidadãs, pelo trabalho.

Nessa direção, a vigente Política Nacional do Ministério da Saúde para a atenção integral dos usuários de álcool e outras drogas observou as prescrições das Conferências de Saúde Mental e da Lei $n^{\circ} 10.216$ também conhecida como Lei da Reforma Psiquiátrica que instituiu um novo modelo de tratamento aos transtornos mentais no Brasil e redirecionou o modelo de atenção, buscando a reabilitação psicossocial das pessoas que sofrem de transtornos mentais e dos usuários de álcool e outras drogas.

Uma das estratégias de cuidado estabelecida na Lei no 10.216 é a Redução de Danos (RD), a definição do objetivo, das metas intermediárias e dos procedimentos não é imposta, mas discutida com o usuário. A interrupção do uso de álcool e de outras drogas quase sempre é um dos objetivos, contudo outros avanços são valorizados, como evitar colocar-se em risco, melhorar o relacionamento familiar e recuperar a atividade profissional. De acordo com o Portal do SENAD (2016), muitas outras dimensões da vida e relacionamento familiar e no trabalho/escola, condições clínicas e psíquicas, relações com a lei, são usadas também para a avaliação do resultado do tratamento. A participação do usuário nas escolhas das metas e das etapas do tratamento valoriza e aumenta a sua motivação e seu engajamento.

Por esse ângulo, segundo a Política Nacional a Atenção Integral a Usuários de Álcool e outras Drogas, do Ministério da Saúde a abstinência não pode ser, então, o único objetivo a ser alcançado. Muito pelo contrário, quando se trata de cuidar de vidas humanas, tem-se que, necessariamente, lidar com as singularidades, com as diferentes possibilidades e escolhas que são feitas. As práticas de saúde, em qualquer nível de ocorrência, devem levar em consideração esta diversidade. Os profissionais de saúde, e dentre estes os assistentes 
sociais, devem acolher, sem julgamento, o que em cada situação, com cada usuário, é possível, o que é necessário, o que está sendo demandado, o que pode ser ofertado, o que deve ser feito, sempre estimulando a sua participação e o seu engajamento no processo de tratamento.

Em suma, levando em consideração as reflexões de Pereira, Vargas \& Oliveira (2011), se a Política foi concebida a partir das demandas sociais, o que lhe confere legitimidade, o Ministério da Saúde e os trabalhadores em saúde mental devem investir muito, a fim de que ofereçam, no futuro, a assistência que desejam para os usuários e para os dependentes de álcool e outras drogas.

Com o objetivo de que isso aconteça, é necessário que se lance mão de uma assistência mais humana, pautada em uma maior sensibilidade para a escuta, desprovida de preconceitos. Essa assistência poderá ser viabilizada pela mudança de atitudes, busca de conhecimentos, aperfeiçoamento de habilidades e reconhecimento da existência do outro considerando o leque de limites e de possibilidades.

\subsection{Substâncias psicoativas e Serviço Social: contextualização com os determinantes sociais da saúde}

É notório que as mudanças ocorridas no seio da sociedade engendradas pela hegemonia do grande capital para responder à crise estrutural capitalista iniciada na década de 1970 afetam de forma inédita as condições de vida e de reprodução social da classe trabalhadora. Nesse contexto, a Questão Social é agudizada e suas expressões são enfrentadas de maneira minimalista e pela articulação de aparatos repressivos (BRITES,2017).

Nesse sentido e considerando o contexto sociopolítico atual, que é marcado por um cenário de regressão de direitos e um conservadorismo em todas as relações sociais, é importante destacar que a realidade do trabalho do assistente social é profundamente afetada por estas questões.

Segundo Brites (2017) a Questão Social vincula o Serviço social aos antagonismos da luta de classes e, consequentemente, as políticas sociais como mediações estratégicas formuladas no âmbito do Estado burguês para responder suas múltiplas expressões de forma a garantir um paradigma de regulação social que assegure a reprodução da ordem do capital (BRITES, 2017).

Nessa direção, e ainda de acordo com a autora supracitada, é na qualidade de trabalhador assalariado que o assistente social é afetado pela precarização das suas condições 
de trabalho e é sob este panorama que ele realiza seu trabalho junto a famílias, adolescentes, mulheres, idosos, população em situação de rua, jovens em conflito com a lei, estudantes, gestantes, trabalhadores desempregados, profissionais do sexo, entre outros segmentos definidos como população prioritária em programas e dispositivos das políticas sociais. Além de que, constantemente se aproxima de situações cotidianas que compreende o comércio e o consumo de SPA's (BRITES, 2017).

Segundo Denadai \& Garcia (2016) é primordial a compreensão de que o uso de drogas faz parte da vida de alguns indivíduos sociais, o que exige uma capacidade crítica para compreender e diferenciar as várias drogas, a diversidade de usos e motivações, bem como os danos sociais e de saúde resultantes dessas práticas. A droga não pode ser apreendida como se ela em si expressasse o fenômeno.

Dito isto e reafirmando que o fenômeno das drogas, e aqui, especialmente, a dependência de substâncias psicoativas, é uma expressão da Questão Social, faz-se necessário elucidar que o tratamento para dependência de substâncias psicoativas encontra-se permeado por muitos desafios e que por isso requer profissionais habilitados, críticos e que saibam compreender as determinações políticas e históricas que perpassam o fenômeno considerando também a influência dos determinantes sociais da saúde neste processo.

De acordo com a Comissão Nacional sobre os Determinantes Sociais da Saúde (CNDSS), os DSS significam, justamente, fatores econômicos, sociais, culturais, comportamentais, étnico-raciais e psicológicos que influenciam diretamente a ocorrência de problemas de saúde e seus fatores de risco na sociedade.

Por outro lado, a Organização Mundial da Saúde (OMS), conceitua como sendo as condições locais em que as pessoas vivem e trabalham e, dessa forma, constituem os fatores sociais, econômicos, culturais, étnicos, psicológicos e também os comportamentais, que influenciam a ocorrência de problemas de saúde e seus fatores de risco na população.

Segundo Ventura (2014) a influência desses determinantes sociais nas condições de saúde foi construído historicamente, reafirmando-se nas discussões para o estabelecimento dos Objetivos de Desenvolvimento do Milênio, no final do século XX, que enfatizaram as relações entre o processo de desenvolvimento e a saúde, com foco nas iniquidades em saúde, por meio do aumento de estudos acerca da pobreza e saúde e os mecanismos de produção de iniquidades individual, comunitário e macro ambiental.

Nessa direção, as iniquidades em saúde representam as desigualdades entre grupos populacionais, que além de sistemáticas e relevantes, podem ser consideradas evitáveis, injustas e desnecessárias. 
Conforme Pellegrini Filho (2006), como exemplo de iniquidade se tem a probabilidade 5 vezes maior de uma criança morrer antes de alcançar o primeiro ano de vida pelo fato de ter nascido no Nordeste e não no Sudeste.

Em consequência disso e considerando os determinantes sociais da saúde por meio das quais os fatores sociais interferem na saúde, é imperativo a exigência de ações para o enfrentamento dos problemas vinculados à saúde, intensificando a capacidade resolutiva das variadas expressões da Questão Social. Sendo ela, uma esfera que manifesta as desigualdades sociais derivadas do modo de produção capitalista - MPC, que se põe como uma peça de produção da vida social. (OLIVEIRA E SANTO, 2013)

Portanto, é neste contexto que o uso e abuso de drogas possui interface com os vários determinantes sociais e segundo Ventura (2014) deve ser enfrentado por meio de execuções e políticas que considerem sua complexidade e as graves consequências que atingem usuários, famílias e sociedade.

Em conformidade com Oliveira \& Guedes (2013) há diferentes compreensões e usos do termo "vulnerabilidade" e aqui, concorda-se com os autores supracitados (2013) no que se refere ao entendimento de que o indivíduo não é ontologicamente vulnerável, mas pode se tornar vulnerável em condições específicas.

Desta forma, estudos revelam a vulnerabilidade de grupos mais jovens, com baixa escolaridade, sem referência familiar, com antecedentes criminais e sem vínculo empregatício, relacionados ao uso de drogas psicoativas. Ainda, em virtude de sua ilicitude, observa-se uma tênue linha demarcatória na construção de ações de enfrentamento ao problema, ora com foco na segurança, ora na saúde pública (VENTURA, 2014).

E como questão de saúde pública, é inegável que os determinantes sociais deste fenômeno, miséria, violência, falta de recursos e investimentos do Estado, ausência de políticas educacionais e culturais e a ruptura de laços familiares e sociais, subsistem na estrutura do problema.

Isso foi evidenciado nos diversos casos em que acompanhei durante o período de estágio no SEAD, no qual constantemente chegavam ao serviço, sujeitos e familiares em situação de vulnerabilidade, com condições insalubres de moradia bem como uma série de direitos violados. Por isso, aqui, a atuação profissional não deve se esgotar na questão do uso de drogas, mas considerar toda a complexidade e o contexto-sócio histórico que aquele sujeito e sua família estão inseridos.

Portanto, é crescente a constatação de que o uso de drogas consiste em desafio, sobretudo, devido ao seu caráter complexo. Neste cenário, impõe-se a necessidade de olhares 
e ações diferenciadas, fundamentadas na compreensão dos usuários como sujeitos, construídos histórico-socialmente.

Segundo Woerner (2015) os serviços para os usuários de substâncias psicoativas devem ser pensados e planejados considerando as características específicas do público atendido, suas necessidades visando o melhor acesso aos serviços. Além disso, as ações devem funcionar de forma integrada, com ênfase na área da saúde mental, atendimento com relação à dependência química. A intervenção profissional pautada em uma postura ética que garantam o respeito à dignidade humana e a garantia de direitos a partir da ação protetiva, e não criminalizadora do Estado, que possibilitem o fortalecimento da autoestima e da condição de sujeito de direitos. 


\section{CAPÍTULO 3: Dependência de substâncias psicoativas e os fatores de adesão: sob o olhar dos usuários do Hospital Universitário de Brasília}

Os profissionais contam muito porque não é qualquer um que ajuda usuários de drogas não, eles têm preconceito [...] Aqui no HUB, as portas estão abertas, sem preconceitos, eles perguntam o que tá precisando, sempre dão auxílio imediato. (usuário, 2018) 


\section{CAPÍTULO 3 - Dependência de substâncias psicoativas e os fatores de adesão: sob o olhar dos usuários do Hospital Universitário de Brasília}

\subsection{Hospital Universitário de Brasília e o SEAD: breve contextualização}

O Hospital Universitário de Brasília ${ }^{20}$ foi inaugurado primordialmente como unidade do Instituto de Pensões e Aposentadoria dos Serviços do Estado - IPASE, por meio do Decreto $N^{o} 70.178$ de 21 de fevereiro de 1972. Durante o regime militar, o estabelecimento foi denominado de Hospital do Distrito Federal Presidente Médici - HDFPM. Posteriormente, em 1987, foi integrado à rede de serviços do Distrito Federal mediante um novo convênio assinado pela Universidade de Brasília com alguns ministérios, passando ser reconhecido como Hospital Docente Assistencial - HDA.

Em 1990, no ano de abril, o Instituto Nacional de Assistência Médica da Previdência Social - INAMPS concedeu o hospital à UnB, em consequência das manifestações públicas empreendidas por parte de alunos e professores a fim de que o hospital fosse administrado integralmente pela Universidade de Brasília.

$\mathrm{O}$ ato requisitou a assinatura à época do Presidente Fernando Collor de Mello e, a partir de então, o hospital passou a se chamar Hospital Universitário de Brasília- HuB. Ao ser incorporado à Universidade de Brasília, o HUB firmou compromisso com a formação de novos profissionais voltados à área da Saúde por meio do desenvolvimento de atividades relacionadas ao ensino, pesquisa e prática de extensão.

Em razão dessa parceria com o ensino, o HUB ficou conhecido pelo atendimento diferenciado das demais instituições de Saúde. O Hospital Universitário conta com uma equipe interdisciplinar e recebe alunos de diversos cursos da UnB, tais como: Medicina, Enfermagem, Nutrição, Farmácia, Odontologia, Administração, Psicologia, Serviço Social, entre outros. Oferece também estágios em muitas áreas destinadas à pós-graduação e nível médio.

Além disso, portanto, sabe-se que a disputa política no campo da Saúde a partir da década de 1970 entre o projeto da Reforma Sanitária e o Projeto Privatista constitui um contexto de tensão na história da política de Saúde brasileira. Nos anos 1990 adota-se no

\footnotetext{
${ }^{20}$ Informações contidas no Site do HuB. Disponível em: < http://www.hub.unb.br> Acesso em: 21 de março de 2019.
} 
Brasil o ideário neoliberal ${ }^{21}$ e apesar dos direitos sociais garantidos na Constituição Federal de 1988 o aparato estatal privilegia na gestão da Seguridade Social o projeto privatista ${ }^{22}$, com consequências para a política de Saúde diante das ofensivas as propostas oriundas do Movimento Sanitarista que luta por uma Saúde pública e universal.

Nesse sentido, o HUB, vinculado à UnB, sofre também os ataques e ofensivas neoliberais, sendo administrado desde meados de dezembro de 2012 pela EBSERH (Empresa Brasileira de Serviços Hospitalares), cuja forma de gestão é a prova mais clara e fomentadora do projeto privatista. No processo de adesão aconteceram alguns debates com os profissionais do HUB, e após votação em reunião do CAD (Conselho de Administração) e paralelo a este processo, ao longo do período, também ocorreu a precarização e o desmonte de alguns serviços prestados pelo hospital que impactam, inclusive, o próprio serviço e o processo de trabalho dos profissionais do SEAD.

É importante enfatizar que a incorporação dessa empresa é considerada como um golpe ao sistema público hospitalar, tendo como justificativa a regularização da situação dos trabalhadores terceirizados. Segundo a cartilha do Conselho Federal de Serviço Social (CFESS) sobre Residência em Saúde e Serviço Social (2017), existem diversos movimentos populares da Saúde que exigem a inconstitucionalidade da EBSERH, pelos seguintes motivos: terceirização de atividades finalísticas nos Hospitais Universitários; a ruptura do caráter dos HUs como uma instituição de ensino vinculada à universidade; e, por fim, a fonte de recursos que torna toda a mercantilização da formação e da pesquisa nesta área uma grande ameaça. Deste modo, infere-se que não há interesse da EBSERH em disfarçar seu caráter privatista.

Nessa direção, considerando todo esse contexto sociopolítico marcado por uma série de ataques e problemas estruturais, está incluso o Serviço Social no SEAD que vive e se reinventa dentro do caos. De acordo com Faleiros (2013) a relação profissional dos trabalhadores está inserta no contexto da produtividade, das exigências burocráticas, da exiguidade de recursos, das normas para reduzir custos, do corte de verbas no neoliberalismo. Todas estas questões apontadas pelo autor foram evidenciadas no HUB.

\footnotetext{
${ }^{21} \mathrm{O}$ ideário neoliberal ganha espaço no imaginário social, como um valor instituído, como a única alternativa de garantia da liberdade e da democracia. Esta situação é amplamente apoiada pela mídia, que incentiva fortemente a abertura dos mercados e principalmente sua auto regulação, descaracterizando a função do Estado como um órgão que deve intervir na economia. (GASPAROTTO et.al, 2014)

22 Este projeto está pautado na política de ajuste, tem como tendência a contenção dos gastos com a racionalização da oferta e a descentralização com isenção de responsabilidade do poder central.
} 
Nesse âmbito, é preciso levar em conta as condições de trabalho e ao mesmo tempo os interesses, os desejos e as demandas da população, que podem ser pessoais e coletivas, exigindo uma diversidade de intervenções e ações com estratégias complexas na correlação de forças em presença.

Ademais, de acordo com Faleiros (2013), as demandas por serviços sociais ou políticas sociais expressam as desigualdades econômicas, de inclusão/exclusão social, de dominação de gênero, de relações de poder e violência nos conflitos familiares, de relação com o crime, com o uso de drogas, com a enfermidade, com a precarização das condições sociais e familiares. Tornando-se demandas complexas tanto por efetivação de direitos como por cuidados específicos que exigem dos profissionais a análise das relações gerais e particulares dessas condições e do poder de enfrentá-las, o que implica trabalhar a correlação de forças (FALEIROS, 2013).

Diante disso, o quadro de pessoas do HUB comporta profissionais de vínculos diferentes, seja de servidores da UnB, empregados da EBSERH, terceirizados, etc. Por fim, em 2017, o HUB assinou um contrato de prestação de serviços com a Secretaria de Saúde do Distrito Federal e passou a ofertar a estrutura do hospital para o atendimento da população do DF, de acordo com os critérios do Sistema de Regulação da Secretaria.

O seu papel principal é no atendimento à Saúde das pessoas, consoante as diretrizes do Sistema Único de Saúde - SUS, criado pela Constituição Federal de 1988, que sob um contexto humanizado e interdisciplinar, asseguram a qualidade e a equidade dos serviços prestados. No entanto, na contemporaneidade, tais aspectos quando materializados são limitados e imbuídos de desafios. Um dos maiores desafios enfrentados pelo hospital atualmente consiste na busca por elevados padrões de qualidade nas atividades de ensino, de serviço e de pesquisa.

\subsection{SEAD - Serviço de Estudos e Atenção a Usuários de Álcool e outras Drogas}

Este tópico visa trazer de forma breve os principais serviços e as atividades realizadas no SEAD, por isso aqui as ações serão descritivas sem tecer julgamento de valor acerca dos serviços oferecidos, uma vez que isso não era o objetivo desta monografia.

O Serviço de Estudos e Atenção a Usuários de Álcool e outras Drogas, primeiramente intitulado de Programa de Atendimento ao Alcoolismo foi criado em 1990 com o intuito de dar suporte às pessoas que buscavam tratamento para problemas com o consumo de álcool no Distrito Federal - DF. 
Por conta de uma crescente demanda por tratamento pelos usuários e dependentes de outras SPAs, o nome do programa passou a não mais corresponder o tipo de trabalho desenvolvido e se fez necessário uma modificação de seu nome. Depois de um longo período de dificuldades burocráticas para a mudança, finalmente em setembro de 2008 o Programa de Atendimento ao Alcoolismo passou a se chamar Serviço de Estudos e Atenção a Usuários de Álcool e outras Drogas- SEAD.

O SEAD destina suas ações às pessoas maiores de 18 anos de idade dependentes de álcool e outras drogas e seus familiares, além de outras atividades voltadas para o ensino e pesquisas relacionadas ao tema. O fluxo para ingresso do usuário de substâncias psicoativas no SEAD é permitido pelo sistema de porta aberta, ou seja, agendamento por telefone ou pessoalmente e ainda "provenientes das solicitações de pareceres das diversas especialidades tanto dos ambulatórios como de enfermarias do HUB, da área de abrangência pactuada (Região Leste), do judiciário e de demanda espontânea. A estratégia de porta aberta é considerada essencial na assistência aos usuários de álcool e outras drogas pois possibilita o acolhimento e a vinculação, facilitando a adesão ao tratamento" (POP/SEAD, 2018).

Nessa direção, nos dias atuais, o SEAD trabalha com questões relacionadas ao consumo abusivo e à dependência do álcool e outras substâncias psicoativas. Para isto, adota a estratégia de redução de danos respaldado no reconhecimento de cada usuário em sua singularidade.

Segundo Brites (2006) a compreensão da condição de sujeito de direitos não pode ser anulada, reduzida ou ignorada em decorrência do uso de psicoativos, independentemente do caráter lícito ou ilícito da substância consumida.

Essa compreensão permite ampliar o acesso, o acolhimento e a vinculação aos serviços de Saúde diversificando as possibilidades de enfrentar os limites e os desafios no que concerne a dependência de álcool e outras substâncias.

O SEAD tem como objetivo geral prestar assistência integral realizada por equipe interdisciplinar ao usuário de substâncias psicoativas e familiares, contemplando ações de orientação, diagnóstico, tratamento e encaminhamento, em ambiente de formação acadêmica, capacitação profissional e produção de conhecimento.

Além disso, tem como objetivos específicos: colaborar no desenvolvimento de estratégias de prevenção e tratamento que beneficiem a população no enfrentamento das questões relacionadas ao uso de álcool e outras drogas; promover ações interdisciplinares favorecendo o desenvolvimento de responsabilidade compartilhada na assistência ao usuário de álcool; e contribuir na formação e capacitação de residentes médicos da psiquiatria, da residência multiprofissional e dos alunos de graduação da área de saúde (PROCEDIMENTO OPERACIONAL PADRONIZADO (POP) - SEAD/ HUB/EBSERH, 2018). 
Para tal, presta atividades diferenciadas e destinadas à resolução das demandas de cada usuário, como: o Ateliê - oficina de trabalhos manuais para pacientes com dificuldades cognitivas, de Psicoterapia entre usuários do sexo masculino e do sexo feminino. Além desses, tem-se o Grupo de família e os atendimentos individuais e familiares. São encaminhados para o SEAD pacientes transferidos de outras clínicas do HUB, instituições públicas e privadas de Saúde do DF e entorno, de órgãos do Poder Judiciário e pacientes ou familiares que procuram o serviço por livre demanda (HOSPITAL UNIVERSITÁRIO DE BRASÍLIA, 2012).

Além do mais, o tratamento ambulatorial oferecido pelo SEAD tem como intuito promover estratégias de enfrentamento do uso intensivo de substância psicoativa, que não só envolve o/a usuário/a de SPA's bem como as demais pessoas ao seu redor.

Para tal fim, e como dito anteriormente, a proposta adotada é a de redução de danos, estabelecida pelo Ministério da Saúde, visando a diminuição de consumo como um dos primeiros passos para o combate ao consumo abusivo de álcool e outras drogas, dentro de todo um processo metodológico interventivo (HUB, 2012).

A equipe interdisciplinar é composta por psicólogas, assistentes sociais, e médica psiquiatra. Todos são imprescindíveis, cada um contribuindo na sua área, para que o tratamento de Saúde seja de qualidade.

É importante salientar que nos termos de Bisneto, (2005)

O médico psiquiatra não leva em conta todas as demandas colocadas pelos problemas de seus pacientes. Para o sucesso da iniciativa tem outros profissionais que complementam o seu desempenho, e a assistente social é um deles. O Serviço social trabalha em conjunto com a psiquiatria, agindo sobre as questões que caso contrário poderão prejudicar o tratamento, quando estas questões não são abordadas por outros profissionais que têm uma especificidade em Saúde Mental mais definida. Para o Serviço social cabem todos genéricos e questões contextuais entendida como social, porque para além do nível biológico ou psicológico. (BISNETO, 2005)

Em suma, os pacientes atendidos no SEAD são sujeitos sociais heterogêneos, com demandas particularizadas, mas que estão ligadas a uma mesma raiz: a Questão Social. São homens e mulheres com uma maior prevalência nos homens. Tem em comum o uso, o abuso ou a dependência de substâncias psicoativas sejam elas lícitas e/ou ilícitas. No cotidiano e na vivência durante o período de estágio, os atendimentos de que participei em sua maioria eram de pacientes homens usuários de álcool ou tabaco. Pacientes que normalmente chegavam ao serviço a partir de uma mobilização a priori por parte da família, e pouquíssimos chegavam ao Serviço por vontade própria (livre demanda).

\subsection{Família, força de vontade do usuário e a socialização de informações}


Cabe lembrar que este é um estudo de um serviço específico que mostra indícios que podem explicar a qualidade da prestação dos serviços ofertados, fatores que interferem na adesão ou não adesão ao tratamento o que era o objetivo aqui proposto. Destarte, faz-se necessário ressaltar que o autor não teve a pretensão de afirmar que os dados são generalizáveis para outros serviços ou programas e tampouco de inferir que todos os serviços acontecem da mesma maneira.

Reiners et.al (2007) diz que a natureza, os sentidos e os determinantes do comportamento de não-adesão são complexos e difíceis de serem entendidos. Por isso, há que se considerar essa questão sob outra ótica, levando em conta a subjetividade do paciente, bem como suas necessidades e dificuldades, mais do que a precisão com que ele segue as recomendações.

Nesse sentido, percebeu-se a partir dos estudos e leituras referente ao tema de pesquisa que o enfoque sobre os fatores de adesão quase sempre se davam a partir da perspectiva dos profissionais de saúde e/ou dos familiares, nessa direção, optou-se por conhecer os fatores de adesão a partir da perspectiva dos próprios pacientes usuários de substâncias psicoativas (SPAs).

Assim, ainda que alguns teóricos definam "adesão" como se manter abstinente em relação à substância utilizada, neste trabalho a compreensão é de que tal conceito pode ir além e entende que a adesão a um tratamento envolve o estabelecimento de vínculo entre o usuário do serviço e a equipe de saúde, de forma que haja o compromisso recíproco nas atividades integradas ao tratamento e, decorrente disso, o favorecimento de mudanças no comportamento em relação ao uso da droga, e não necessariamente uma ruptura abrupta do uso da substância psicoativa.

Os dados foram colhidos por meio do levantamento de informações presentes nas reuniões e nos documentos institucionais dos nove sujeitos participantes desta pesquisa no período de estágio obrigatório no SEAD. As substâncias mais utilizadas pelos sujeitos são o álcool, seguido do tabaco, isto é, substâncias lícitas e que têm implicações na saúde tanto quanto as ilícitas. Dessa maneira, apesar de o autor se referir de um modo geral sobre as implicações do uso de SPAs na vida dos sujeitos se dará uma maior ênfase no uso de álcool.

Segundo o Centro Brasileiro de Informações sobre Drogas Psicotrópicas (CEBRID) o álcool é uma das poucas drogas psicotrópicas que têm seu consumo admitido e até incentivado pela sociedade. Apesar de sua ampla aceitação social, o consumo de bebidas alcoólicas, quando excessivo, passa a ser um problema. Além dos inúmeros acidentes de trânsito e de violência associada a episódios de embriaguez, o consumo de álcool a longo 
prazo, dependendo da dose, frequência e circunstância pode provocar um quadro de dependência.

Dessa forma, o consumo excessivo de álcool é um relevante problema de saúde pública, sobretudo nas sociedades ocidentais acarretando altos custos para a sociedade e envolvendo questões médicas, psicológicas e familiares (CEBRID, 2015).

\subsubsection{Perfil dos usuários do SEAD}

Verificou-se que todos os usuários deste estudo, são do sexo masculino, com idade entre 41 e 60 anos, a maioria são divorciados seguidos de solteiros e outros não informados. A religião predominante dos sujeitos é o catolicismo.

Dos nove pacientes, cinco têm o ensino médio completo e quatro cursaram até o ensino fundamental. Além disso, sete sujeitos possuem filhos, e dois não. Em relação ao apoio de familiares no tratamento, todos dispõem de participação familiar. Observou-se que o apoio é marcado majoritariamente por familiares do sexo feminino, o que corrobora com a literatura no que diz respeito ao atribuir o cuidado em saúde como uma questão quase que naturalmente feminina. Sobre como conheceram e chegaram até o serviço especializado a maioria foi encaminhado por familiares, ou de profissionais de saúde e três pacientes chegaram ao serviço por livre e espontânea vontade.

A partir da análise dos relatos dos pacientes no grupo focal, serão aqui apresentados e discutidos os temas e significações que resultaram nas seguintes categorias temáticas:

1) Estigmas e preconceitos enfrentados por serem usuários de substâncias psicoativas

2) Motivação e busca por tratamento e problemas no início do processo de tratamento;

3) Mudanças na qualidade de vida;

4) Fatores que interferem no processo de adesão: sob o olhar dos usuários

5) As possibilidades e os limites do trabalho do assistente social.

\section{1) Estigmas e preconceitos enfrentados por serem usuários de substâncias psicoativas}

Quando indagados a respeito dos problemas que os sujeitos achavam que os usuários de substâncias psicoativas enfrentam foi interessante perceber que em quase todos os relatos aparecia a questão do estigma bem como dos problemas relacionados a saúde mental. Segundo Goffman (1978) o estigma é uma construção social que representa uma marca a qual atribui ao seu portador um status desvalorizado em relação aos outros membros da sociedade. Ocorre quando os indivíduos são identificados com base em alguma característica indesejável 
que possuem e, a partir disso, são discriminados e desvalorizados pela sociedade. Esse tipo de estigma é chamado de estigma social, ou público (GOFFMAN,1978).

De acordo com o entendimento ora supracitado, é presumível inferir que ao chamar um usuário de substância psicoativa de "drogado" é como se tivéssemos reduzindo tudo que o sujeito é, (em sua complexidade) em apenas uma prática social. Dessa maneira, o termo usuário de substâncias psicoativas é mais coerente com a linguagem e a ética profissional pois implica em reconhecer que esta prática é uma entre as inúmeras práticas, atividades, escolhas, possibilidades e potencialidades daquela pessoa. (BRITES, 2015)

Nos termos de Brites (2015), o termo drogado está saturado de visões estigmatizantes e incompatíveis com a ética, por exemplo, dos assistentes sociais, e fundamenta dizendo que chamar os indivíduo de drogados, é como se esta prática social - o uso da substância psicoativa - aniquilasse a totalidade de sua personalidade, de suas escolhas, de sua moralidade, de sua condição social e profissional, reduzindo-a à condição de drogada. Isso é evidente nas falas a seguir:

Algo muito ruim e que machuca, é quando as pessoas nos chamam de drogados, vagabundos, mau caráter. (usuário 5., 2018)

Eu penso do preconceito que a gente sofre[...] e isso aí a pessoa se sente mal. (usuário 3.,2018)

Quando chegamos nos lugares, eles pensam, tá chegando o pé inchado, drogado, chegou o beberrão, já vai ter confusão[...] é única coisa que eles pensam[...] nós somos malvistos. (usuário 4.,2018)

Além do mais, e apesar dos escassos estudos sobre a relação da depressão com o uso de substâncias psicoativas, a categoria depressão apareceu duas vezes em relatos diferentes, bem como a categoria preconceito e humilhação. Isso nos evidencia o quão difícil é ser usuário de álcool e outras drogas e que devido a este fato os sujeitos sofrem duas vezes, primeiro por ter que conviver com os problemas decorrentes da própria condição de dependente e segundo por ter que lidar com pessoas na sociedade que não entende que esta questão é uma doença multifatorial ${ }^{23}$ e que tem de ser encarada com muita seriedade.

As pessoas não sabem que isso é uma doença, doença grave que às vezes não tem nem cura. (usuário 2.,2018)

\footnotetext{
${ }^{23}$ As doenças multifatoriais são o resultado de complexas interações entre fatores genéticos e ambientais, assim são também denominadas de doenças complexas (Bossoni \& Oliveira, 2009).
} 
Uma depressão, a gente sente oprimido, pensa que ninguém é por nós" (usuário $1 ., 2018)$

Sinto depressão, humilhação, vontade de suicídio, eu já tive essas coisas, tentei várias vezes, mas não consegui (usuário 2.,2018)

Faz-se necessário salientar que a reprodução dos estigmas e dos preconceitos pode se dar em consequência da falta de compreensão da dependência como sendo uma doença. Segundo a Organização Mundial da Saúde (OMS) a dependência química está classificada entre os transtornos psiquiátricos, sendo considerada uma doença crônica que pode ser tratada e controlada simultaneamente como doença e como problema social ${ }^{24}$ (OMS, 2001).

Além disso, vale frisar que os estigmas quando passados de geração para geração e naturalizados por grande parte da sociedade tem implicações danosas na vida do sujeito dependente da substância psicoativa. Em conformidade com Ronzani \& Furtado (2010) o processo da formação do estigma tem características negativas atribuídas pela sociedade e são internalizadas pelos estigmatizados trazendo consequências nas três esferas da vida, são elas: social, psicológica e na saúde.

Social: inclui problemas familiares, exclusão social, desemprego e disparidades sociais;

Psicológica: presença de sentimento de culpa, vergonha, raiva, angústia e baixa autoestima;

Saúde: agravamento de sua condição, dificuldade ou recusa em buscar ajuda e baixa adesão ao tratamento.

Figura 1. O processo da internalização do estigma

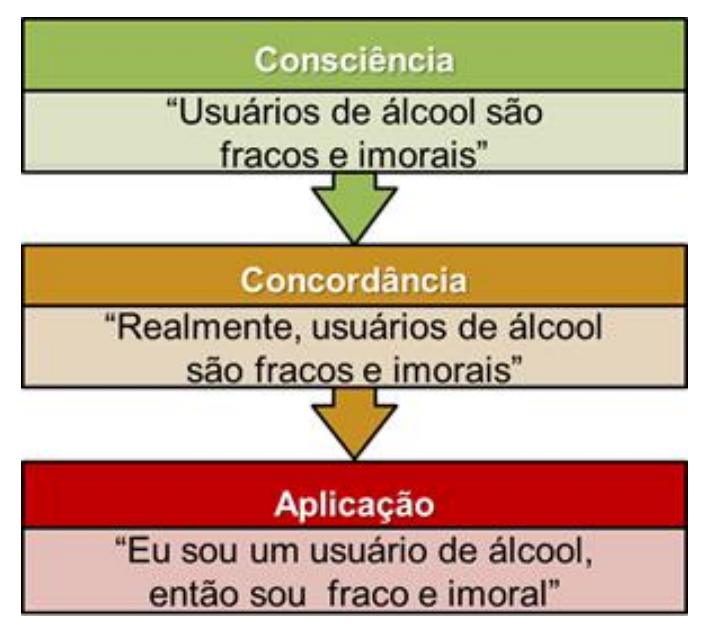

Adaptado de Ronzani \& Furtado (2010)

\footnotetext{
${ }^{24}$ Cabe ressaltar que aqui está se referindo a uma citação da OMS que fala de "problema social". Em outros estudos do Serviço Social é que se faz uma referência à categoria Questão Social.
} 
Eu sou alcoólatra, já tenho 25 anos que bebo e eu tô com 42 anos, eu sou crônico, eu não consigo parar de uma vez, quero parar, mas não é fácil. (usuário 3.,2018)

Considerando essa não compreensão, o que se enfatiza é que de tanto a sociedade rotular e estigmatizar os sujeitos eles mesmo se apropriam dos termos e começam a se identificar como tais. Além de que, os estigmas começam a aparecer no interior do próprio seio familiar do sujeito, implicando em conflitos familiares e isolamento social uma vez que a própria complexidade da dinâmica da dependência impede que os familiares compreendam e voltam-se a concluir a questão como desvio de caráter, falta de vergonha na cara, etc.

Nessa direção, Faria et.al (2016) nos mostra que as informações deturpadas transmitidas pela mídia, somadas à falta de conhecimento sobre o transtorno, fazem com que os usuários de drogas sejam temidos e vistos como incapazes de se recuperar. Deste modo, sofrem com a desconfiança, estereótipos negativos, preconceitos e discriminação (FARIA et.al, 2016). Isso se evidencia a partir do seguinte depoimento:

[...] E o preconceito é dentro de sua casa no bem dizer[...] pq as vezes seu filho, sua mulher te xingam "seu drogado, seu cachaceiro" e isso aí a pessoa se sente mal. (usuário 5.,2018)

Dito isso, é possível inferir que as consequências dos estigmas são adversas no processo de tratamento dos sujeitos e na vida dos indivíduos, pois é sabido que os usuários de drogas sofrem constantemente com os efeitos prejudiciais do processo de estigmatização. Assim, segundo Faria et.al (2016) as principais consequências são perda da autoestima, restrição das interações sociais entre outras.

Conforme Ronzani \& Furtado (2010) uma estratégia utilizada para erradicar os estigmas, é a educação que deve disseminar a informação de que a dependência é uma doença, e assim como outras doenças crônicas (diabetes e hipertensão, por exemplo) precisa de tratamento como também no empenho de eliminar o uso de jargões, como o termo "alcoólatra". 25

Outra indagação que chamou a atenção, foi que dois pacientes declararam sobre a questão da medicação como um problema a ser enfrentado. Observou-se que por não conseguirem parar de fazer o uso das substâncias, os pacientes entendem que a medicação não tem efeito e que este é o motivo da não adesão.

Desta forma, eles esperam do Serviço uma medicação quase que milagrosa, isto é, algo material que dê algum sentido e não apenas a rede de conversas. Conforme Ferreira et.al

\footnotetext{
${ }^{25}$ Destaque com aspas, pois é um termo estigmatizante.
} 
(2015) o uso de medicação é um fator que influencia na adesão ao tratamento, uma vez que alguns dependentes de SPA's têm a ideia ilusória que somente usando medicamento conseguirão a reabilitação e, por isso, não aderem ao restante das atividades propostas. Entretanto, o tratamento medicamentoso é apenas um dos recursos terapêuticos que devem ser complementados com estratégias para mudanças comportamentais e planejamento terapêutico de vida.

A gente precisa de informação, porque a gente sabe que tem remédio, será se vai rolar remédio ou se vai ser só a rede de conversas? (usuário 2.,2018)

Além do mais, é importante salientar o destaque referente aos problemas que as drogas trazem em relação à convivência familiar. Constata-se que a dependência é um problema que afeta as dimensões individual, social e familiar. Desta forma, interfere diretamente nas relações familiares, o que muitas vezes acaba gerando discussões, estigmas, e como dito anteriormente, o isolamento social.

A família, vivenciando essa situação, muitas vezes, se depara com uma realidade com que não está preparada para lidar, e todos seus integrantes são afetados por ela. Por isso, tratase de um fenômeno circunscrito ao desenvolvimento familiar e que acontece em qualquer classe social (REIS \& MOREIRA, 2013). Ademais, as perdas afetivas e financeiras se mostraram preponderantes a partir dos relatos. Muitos afirmam ter perdido empregos e oportunidades de ascensão social devido a dependência de álcool, e dois pacientes relataram ter passado por problemas no trabalho, tais como: faltas constantes devido a ressaca, atrasos injustificados e até episódios de embriaguez durante o expediente.

De acordo com Lopes et.al (2015), o consumidor excessivo de álcool passa por uma sucessão de crises, das muitas consequências familiares relatadas pelos sujeitos, destacam-se: ter de conviver com os efeitos físicos do álcool, acidentes de trânsito, constrangimentos, isolamentos, perdas econômicas e sociais. Dessa maneira, levando-o, muitas vezes, a exclusão, não só da família, mas também de toda a rede social que o circunda, evidenciando situações vivenciadas de preconceito com o ato de beber em magnitude.

Têm vários problemas, porque esses problemas de vício tem dois caminhos, se a pessoa não se cuidar, cemitério ou cadeia, o álcool é mais cemitério[...] por causa dele, perdi emprego bom, fui cortado no meio do caminho, por causa de quê? álcool[...] em casa, qualquer coisa era tudo no grito, só sabia brigar, e isso só gerava mais problemas com minha família. (usuário 5.,2018)

Diversos problemas, antigamente eu era excluído das festas de família, hoje em dia eles fazem é questão, e eu que não quero ir porque sei que vai ter bebida. (usuário 4.,2018) 
Para além de tudo isso, o que se mostrou também interessante foi o fato de que dos 9 pacientes apenas 1 não se reconhece dependente da substância psicoativa. Compreende-se que no começo de um tratamento para dependência o paciente passa por várias fases, umas delas é a de pré contemplação, compreendida como um estágio em que não há intenção de mudança nem mesmo uma crítica a respeito do conflito envolvendo o comportamento problema.

De um modo geral, segundo Jungerman \& Laranjeira (1999) a pessoa neste estágio sequer encara o seu comportamento como um problema, podendo ser chamado "resistente" ou "em negação". ${ }^{26}$ Embora os problemas decorrentes do uso da substância psicoativa sejam visíveis na vida do indivíduo, quando indagados a respeito dos problemas, este inclinou-se e minimizou os efeitos. No entanto, faz-se necessário frisar que o paciente supracitado foi o último a começar o tratamento, e que no período da coleta de dados tinha pouco menos de duas semanas que estava inserido, o que é compreensível essa sua condição de pré contemplação.

Confirmando essa perspectiva, estudo com 103 adolescentes usuários de drogas em tratamento psicoterapêutico, em Porto Alegre, explanou que a maioria dos participantes que não aderiram ao tratamento $(69,3 \%)$ se apresentava em estágio motivacional de précontemplação, ou seja, não havia a percepção da impotência perante o vício e não acreditavam ter problemas decorrentes dessa prática. (OLIVEIRA et.al, 2010)

Eu não tenho nem ideia, eu pelo menos uso, mas trabalho[...] não estou aqui, eles disseram que eu tô dependente, negativo, desde que dei entrada aqui não bebo e não tô com vontade, não sou dependente." (usuário 7.,2018)

Além disto, e ainda com relação aos problemas enfrentados pelos usuários de substâncias psicoativas, é importante elucidar duas questões que apareceram em 4 relatos dos 9 pacientes. O primeiro se refere a falta de informação acerca da existência de tratamento especializado para os usuários de drogas e o segundo sobre as dificuldades existentes em ter de viver em locais onde se estimula o consumo.

Um dos pacientes relata que o SEAD não tem muita visibilidade e que a maioria dos sujeitos procuram somente os CAPS, e como estes estão com déficit de profissionais, os pacientes até iniciam o tratamento, mas acaba não aderindo o que implica em recaídas e a inviabilização do tratamento.

Em conformidade com Ferreira et.al, o ambiente é um fator que interfere na adesão, por exemplo, muitos pacientes residem com outros usuários de drogas ou próximos de

${ }^{26}$ Destaque do autor 
traficantes, bares e de locais de uso de drogas, favorecendo o contato diário com essas substâncias.

Uma das dificuldades é conviver nos ambientes que estimulam o consumo, os locais onde tá todo mundo bebendo, por exemplo, eles pensam, tá chegando o pé inchado, chegou o beberrão, já vai ter confusão (usuário 9.,2018)

Tem muita gente que vive nessa vida aí pq não sabe que tem tratamento, tem muita gente que não tem informação, quase ninguém sabe desse tratamento no HUB, eles procuram mais o CAPS. (usuário 8.,2018)

Como se vê, diversas são as implicações na vida dos usuários no que se refere a estigmas, depressão, desconhecimento da dependência como uma doença etc., nessa direção, é importante destacar a necessidade em rever os conceitos e refletir sobre, a fim de apreender se tais conceitos imprimem um caráter emancipatório ou (re)vitimizam os sujeitos. Além disso, a socialização de informações a respeito do tema faz-se de extrema relevância, sobretudo no que se refere a compressão de que a dependência química é uma doença e não uma questão moral.

\section{2) Motivação e busca por tratamento}

Ao questionar os usuários a respeito de como eles chegaram ao tratamento, as respostas confirmaram o que a literatura diz, segundo Ferreira et.al (2015) os pacientes que iniciam o tratamento apenas em decorrência de influências externas, como: pressão familiar e de amigos, encaminhamentos de profissionais e ordens judiciais, possuem dificuldade em aderir ao tratamento, pois não se sentem realmente motivados para o mesmo. Nesta direção, dos 9 pacientes, somente 3 afirmaram ter procurado o tratamento por livre e espontânea vontade.

Foi por causa da minha família, eu estava em casa, bebendo demais, e aí minha mãe falou: vai procurar um tratamento, eu peguei e vim (usuário 1.,2018)

Vim através de uma assistente social do órgão que eu trabalho[..]ela me encaminhou pra cá, porque eu estava tendo problemas com o álcool (usuário $3 ., 2018)$

Observa-se que apesar da maioria ter iniciado o tratamento por influências de familiares e profissionais da saúde, o que nos mostra um indício da dificuldade de adesão, 3 disseram ter procurado o tratamento depois de não conseguir mais viver sofrendo devido às implicações da dependência. 
Eu vim aqui por livre espontânea vontade, porque eu não aguentava mais, sofria muito, e eu queria parar e não conseguia (usuário 3.,2018)

Eu mesmo não tive apoio da minha família não, eu mesmo que meti os peitos e vim. ninguém veio me trazer aqui não”. (usuário 2.,2018)

Eu mesmo procurei, depois de quase 30 anos, não sabia, e já tem 16 anos que eu faço tratamento, mas de vez em quando tenho recaídas, é muito difícil. (usuário 4.,2018)

Quando indagados sobre a qualidade do tratamento oferecido no Serviço, os pacientes foram unânimes em afirmar que o tratamento é eficiente.

Ah pra mim, é muito bom, você passa primeiro pelo acolhimento com a assistente social, psicologia, psiquiatria, aí tem a medicação certa. muito bom (usuário 3.,2018)

Quando cheguei no SEAD minha vida mudou, não precisei ser mais internado (...) agora tô tranquilo. o atendimento de vocês aqui é muito bom (usuário 2.,2018)

O que eu posso falar é que tenho muito pra agradecer pelo tratamento que é oferecido aqui. (usuário 6.,2018)

Se a nota for 10 pra mim é 10[..] são muitos pontos positivos, estou satisfeito, o apoio das doutoras, as conversas, os colegas aqui dividindo os problemas, você aprende é muito. (usuário 4.,2018)

No entanto, apesar dos relatos comprovarem que a avaliação dos pacientes a respeito do tratamento oferecido é eficiente, foi notável perceber que todos ao contarem sobre as dificuldades, contavam a dos outros e nunca as deles mesmos. Sobre isso, 8 pacientes afirmaram a princípio não terem enfrentado nenhum problema, porém ao desenvolverem o argumento, era possível identificar alguns desafios enfrentados.

Desafios estes que tem a ver com as condições socioeconômicas dos pacientes. Sabese que as condições de trabalho e de vida dos indivíduos interferem diretamente na saúde e nos tratamentos desta natureza, e com a questão da dependência química isso não seria diferente.

Em conformidade com Ferreira et.al (2015) as condições socioeconômicas são fatores intimamente relacionados à baixa adesão ao tratamento, por exemplo, alguns pacientes não podem se ausentar do seu trabalho, pois necessitam manter a renda familiar; e até mesmo por não possuírem recursos financeiros para a locomoção.

Eu mesmo não tive nenhuma, mas tem pessoas que não tem dinheiro da passagem, não tem ninguém que traz, não tem renda pra vim pra cá, eu não tive. (usuário 3.,2018) 
Não tive dificuldades, mas é difícil, quando vier à vontade tem que repreender, eu mesmo conheço gente que não consegue se segurar (usuário, 2.,2018)

Não tive nenhuma dificuldade, as portas sempre estavam abertas, eu me sentia incapaz, o pessoal que me ajudou”. (usuário 1.,2018)

Um deles afirmou ter enfrentado dificuldades no início e mais ainda para permanecer no tratamento, pois devido às dificuldades financeiras e a distância do local sua permanência neste ficou comprometido. Porém ao compreender que o seu tratamento é importante para a sua qualidade de vida, e reconhecer os ganhos secundários que o tratamento lhe proporciona, como: o apoio das doutoras, as conversas com os colegas que estão como o mesmo problema e as lições aprendidas a cada reunião, conta como se dá a logística e o gerenciamento para não faltar às reuniões e as consultas.

A única dificuldade minha foi porque devido eu morar longe, foi o transporte [..] não posso andar de ônibus, porque quando entro passo mal[..] então tenho que vir de carro, e você sabe que o preço da gasolina tá absurdo, cada viagem da minha casa pra cá é $100 \mathrm{~km}[.$. ] já teve consulta que não vim por falta de combustível[..] mas faço das tripas ao coração para não faltar. (usuário 6.,2018)

Por fim, é importante salientar que os problemas enfrentados pelos usuários de substâncias psicoativas que obsta a continuidade destes no processo de adesão ao tratamento apesar de se expressarem de diversas formas na vida social de cada um, tem uma raiz comum, que é: a Questão Social. Nessa direção, infere-se que as condições de vida e de trabalho das pessoas, bem como as condições socioeconômicas influenciam significativamente no processo de adesão.

\section{3) Mudanças na qualidade de vida}

Com relação às mudanças ocorridas nos aspectos individuais, sociais, e familiares após o início do tratamento, os 9 pacientes afirmaram ter tido mudanças significativas, sobre isso dividirei em três categorias que apareceram com mais frequência, a saber: autocuidado, convivência familiar, e melhoras na questão financeira.

Alguns pacientes relataram que após o início do tratamento para dependência de substâncias psicoativas, embora não tenham conseguido se manter abstinente por completo, tiveram melhoras significativas na qualidade de vida. Sobre os aspectos do autocuidado, dois pacientes afirmam ter tido melhoras no cuidado da higiene, o cuidado com o corpo e que depois que começaram a frequentar o SEAD, deixaram de viver nas ruas.

Melhorou muito, eu nem fazia mais a barba, não tomava banho só queria saber de beber, dormia na rua junto com os mendigos, hoje eu tô em casa com a minha mãe e ela está mudando a expressão comigo (usuário 5.,2018) 
Além disso, alguns chegam a dizer que se tivesse continuado na "vida que estava" talvez nem estivessem mais vivos. É indiscutível que a questão da dependência obsta a liberdade do indivíduo de ser quem ele é, nesse sentido, sob os efeitos das substâncias psicoativas, o indivíduo fica refém da substância e o seu querer já não é mais levado em consideração.

Minha vida mudou muito, aprendi a me cuidar mais, as vezes poderia até tá morto continuando na vida que eu estava”. (usuário 5.,2018)

Sobre as melhorias na convivência familiar e na questão financeira, os pacientes relatam que por causa da dependência quase nunca ficavam em casa. Com isso, os laços familiares tornam-se frágeis. Assim, quando retornavam para a residência alcoolizados, o que se tinha eram mais discussões e brigas constante.

Em consequência disso, ficavam isolados da família e perdiam comemorações familiares importantes. Pode-se inferir que com toda essa problemática da dependência somado ao isolamento social, a questão da saúde mental do sujeito fica comprometida e isso pode ser mais um gancho para continuar fazendo uso de drogas.

Por outro lado, após o início do tratamento, pacientes relatam que a partir da psicoterapia com a psicóloga, acolhimento com a assistente social e com a psicoeducação com a médica psiquiatra aprenderam mecanismos para conseguir se controlar no que se refere a impulsividade.

A minha mudou pra melhor porque eu só bebia na rua, hoje eu parei e convivo com minha família, antes eu não convivia. (usuário 6.,2018)

Nossa, melhorou muito em casa, eu não sabia dialogar, hoje eu já sei, só sabia gritar, tudo era no grito[..] agora eu já sei contar até 10 para responder uma questão que antes era no estouro. (usuário 4.,2018)

Além disso, após ter parado por completo ou diminuído em partes o uso de drogas, uma questão levantada por 3 pacientes dos 9 foi a referente a questão financeira. Os pacientes relataram que gastavam muito para sustentar a dependência da SPA's e que devido a isso os problemas financeiros eram constantes. No dia seguinte após o uso de substâncias, sentiam-se arrependidos pelo tanto que gastaram e por caírem a ficha de que tudo foi em vão.

Melhorou muito, antes no outro dia era uma tristeza quando olhava pro bolso, pensava[..] dava pra comprar isso, aquilo, né? agora já era, ficava tudo no bar. (usuário 5.,2018) 
Melhorou porque o dinheiro sobra, você consegue fazer mais coisas, quando bebia a gente não liga muito, a metade do meu salário ia pro boteco. (usuário 2.,2018)

Melhorou, uma vez mesmo eu fiquei pensando[...] deixei 350 contos num boteco, pensei[..] que merda eu tô, fazendo da minha vida? 300 contos davam pra fazer muita coisa e gastei tudo com cachaça[..] queria parar, mas não conseguia ficar sem beber. parece um círculo vicioso. (usuário 5.,2018)

Em síntese, como visto anteriormente, as mudanças ocorridas na vida dos sujeitos foram consideráveis, algumas em maiores, outras em menos graus, mas todas com as suas particularidades na vida de cada um. Assim, o que fica de lição é apreender o quanto que um tratamento humanizado, pautado na ética profissional e com vinculação e acolhimento em todo o processo de saúde traz reverberações na saúde dos indivíduos.

\section{4) Fatores que interferem no processo de adesão: Sob o olhar dos usuários}

Sobre as principais respostas acerca dos fatores que interferem no processo de adesão, todos os 9 pacientes afirmaram a importância do apoio familiar, 5 mencionaram a questão da força de vontade do próprio paciente; 1 sobre profissionais comprometidos com a temática álcool e outras drogas e 3 sobre a importância de haver socialização de informações e divulgação a respeito do tratamento especializado.

O tratamento para dependência de substâncias psicoativas é complexo e permeado por muitos desafios. Assim, é notório que embora a força de vontade seja de extrema importância para o sucesso da adesão ela por si só não é suficiente.

Pois é necessário um Serviço de Saúde especializado, equipado, com os recursos humanos e materiais necessários bem como o engajamento tanto dos profissionais quanto dos pacientes em prol de um mesmo objetivo. Foi interessante perceber que todos os sujeitos se reconhecem como o principal agente causador de suas mudanças, o que de uma certa forma é verídico, contudo, a qualidade dos serviços prestados bem como o comprometimento dos profissionais, que engloba acolhimento e não preconceito, são elementares neste processo.

Isso depende de cada um, depende da pessoa, depende de mim, porque se eu não vier as portas estão abertas e eu que vou perder a oportunidade que é única. (usuário 2.,2018)

A pessoa tem que ter esforço, quando eu fui internado eu ainda não estava no fundo do poço[...] a pessoa tem que procurar, e ter a ajuda, a família tem que ajudar, ela é a base. (usuário 9.,2018)

Os profissionais contam muito, porque não é qualquer um que ajuda usuários de drogas não, eles têm preconceitos[...]Aqui no SEAD, as portas estão abertas, sem preconceitos, eles perguntam o que tá precisando, sempre dão um auxílio imediato”. (usuário 8.,2018) 
De acordo com Ferreira et.al (2015) o serviço de saúde favorece a adesão ao tratamento, desde o acolhimento inicial do dependente de SPA's na instituição, sem uso da violência e preconceito, com estabelecimento de vínculo entre profissional e paciente. Portanto, sem vínculo, em um local nada acolhedor e (re)vitimizados pelos estigmas, os pacientes não aderem ao tratamento e não retornam ao serviço.

A família, por outro lado, tem um papel importante e corrobora com o que a literatura vem declarando. A influência familiar mostrou-se unânime na percepção dos participantes da pesquisa. Considerando que a dependência química causa grande impacto e sofrimento a todos os membros da família, esta, muitas vezes, está adoecida e precisam de um apoio especializado para que consigam apoiar seus familiares e auxiliá-los na permanência do tratamento bem como colaborar na qualidade de vida.

Atualmente, as famílias são uma grande fonte de ajuda no tratamento da dependência, pois se considera a família como um sistema que necessita de orientação e acompanhamento para que o resultado do tratamento seja mais eficiente (CARDIM \& LOURENÇO).

A família ajuda, meu filho no começo vinha, já apoiou, mas hoje pela carreira dele, ele não está mais em Brasília, mas de longe me dar força. (usuário 1.,2018)

No meu ponto de vista tinha que ter um apoio da família primeiro, do filho, de uma esposa. o cara vem aqui sozinho, vem uma vez, duas vezes e desiste, não tem apoio de ninguém. ele tendo um apoio da família, ele está vendo que a família está preocupada com ele (usuário 4.,2018)

Apoio da família, se a família não ajudar, o cara desiste. (usuário 6.,2018)

Além disso, outra questão que se mostrou preponderante e que de acordo com os pacientes é imprescindível na interferência da adesão é o fato de existirem profissionais comprometidos com a questão do álcool e outras drogas, e aqui se incluem os assistentes sociais, que têm de compreender a questão do uso de drogas sob uma perspectiva crítica e como expressão da Questão Social conforme mencionado em capítulos anteriores.

Só assim, sob a compreensão da perspectiva crítica é que é possível intervir na questão de forma qualificada e passar a apreender as expressões desvinculadas de preconceitos, e estigmas. Segundo Brites (2015) os aspectos da questão das drogas devem ser apreendidos criticamente pelos assistentes sociais, uma vez que o trabalho profissional se vincula à defesa da democracia, da justiça social com equidade, dos direitos humanos e ao combate de todas as formas de preconceito e de violação de direitos.

O que eu posso falar é que eu tenho muito que agradecer pelo tratamento oferecido aqui, clínica médica, psicológica, psiquiátrica[..] (usuário 4.,2018) 
Depois que cheguei aqui no SEAD minha vida mudou, não precisei ser mais internado[..] agora tô tranquilo, o atendimento de vocês aqui é muito bom. (usuário 3.,2018)

É muito bom, você passa primeiro pelo acolhimento com assistente social, psicologia, psiquiatria, aí tem a medicação certa. muito bom. (usuário.6,2018)

Como se vê, o modo como os profissionais tratam os sujeitos interferem muito no processo de adesão, visto que, muitas vezes, os pacientes já vivenciam na pele diariamente o tratamento com indiferença, violência e preconceito, assim, eles esperam do serviço de saúde um lugar que seja de acolhimento e tratamento humanizado.

Por fim, e nessa direção, segundo Ferreira et.al (2015) a capacitação dos profissionais e as aptidões para trabalhar com essa área interferem na adesão do paciente, atuar com uma equipe que os profissionais não gostam de trabalhar com a saúde mental e com a questão do álcool e outras drogas, interferirá no modo de fazer, orientar e intervir.

\section{Os limites e as possibilidades do trabalho do assistente social frente à temática do uso de álcool e outras drogas}

É inegável que a intervenção do assistente social como dito anteriormente, é de extrema importância frente à temática álcool e outras drogas pois o Serviço Social tem uma responsabilidade na sua contribuição na forma de compreender o fenômeno como uma das expressões da Questão Social.

Esta compreensão fundamenta-se na perspectiva que ultrapasse a garantia de direitos e volta-se para a construção de uma nova sociabilidade. Os cuidados com a saúde apresentam-se como uma necessidade social, somado a necessidade de um espaço democrático que garanta a acolhida, visto que, os principais problemas apresentados relacionam-se com as situações de ruptura e risco sociais inerentes ao uso/abuso e dependência da droga.

Somado a isso, cabe lembrar que muitos são os limites e as possibilidades vivenciadas constantemente pelos profissionais quando da sua atuação junto aos indivíduos que fazem uso de álcool e outras drogas. Nessa direção, e atendendo a segunda parte do objetivo desta pesquisa buscou-se compreender quais eram os limites e as possibilidades do trabalho do assistente social.

Considerando isso, foi interessante perceber que as três profissionais participantes relataram que os maiores limites eram referentes a omissão do Estado frente a esta temática; inexistência de verbas para uma maior qualidade dos serviços prestados a esta população e a 
fragilidade no acesso, comunicação e atendimento com a rede. Isso se corrobora a partir da seguinte fala:

\begin{abstract}
Por se tratar, no SEAD, de um atendimento ambulatorial, a necessidade de encaminhamento para realização de procedimentos como de desintoxicação são constantes. [...] pacientes relatam diversas dificuldades, como a falta de estrutura adequada, insuficiência de profissionais, tratamento inadequado, dificuldade de compreensão sobre o funcionamento e organização da rede de serviços. (assistente social 1.,2018)

Os limites mais frequentes são: acesso a leitos na rede pública para internação quando há comprometimentos clínicos e psiquiátricos, demora na entrada e no recebimento dos benefícios sociais, inexistência de medicação específica para tratamento da dependência na rede pública, dificuldades de acesso a serviços da rede de saúde próximos à residência do usuário, entre outros. (assistente social 3.,2018)
\end{abstract}

Além desses, uma profissional mencionou um limite interessante que foi em relação a autonomia da Universidade de Brasília e consequentemente do Hospital Universitário e de como a nova gestão EBSERH limitou muitas atividades e prejudicou os processos de trabalho.

Cabe lembrar-nos que a EBSERH é definida como uma empresa prestadora de serviços, que se expressa enquanto uma ferramenta política de favorecimento do mercado por meio da expansão e estímulo ao projeto privatista empenhado pelo Estado, mas também se destaca por sua perspectiva lucrativa, tendo como essência o caráter de rentabilidade econômica expressa na mercantilização da saúde e da educação. (FERNANDES, 2014) Dito isso, a profissional assegura que:

As dificuldades gerais que vivenciam atualmente as universidades e os hospitais escola, além da gestão da EBSERH/MEC tem provocado importantes inquietações e reflexões acerca do processo de trabalho e da autonomia da Universidade. O que se tem são: instalações inadequadas, insuficiência de recursos para capacitação e atualização profissional, defasagem no quadro de pessoal e precariedade nos processos de trabalho. (assistente social 3.,2018)

As profissionais relataram ainda o quanto os limites institucionais, econômicos e políticos influenciam na adesão do próprio paciente ao tratamento para dependência química. E que estes, por chegarem ao serviço com muitos direitos já violados e com determinantes sociais de saúde que impactam negativamente na qualidade de vida passam por muitas dificuldades em aderir o que é proposto. Sobre estas, destacam-se: questões relacionadas à distância entre o local de residência e o hospital, custos com a locomoção, impasses ao acessar outros serviços na rede, dentre outros. 
Por outro lado, e a respeito das possibilidades dos assistentes sociais na atuação referente a temática álcool e outras drogas, embora o cenário atual seja de contrarreformas do Estado e marcado pela expropriação de direitos (BEHRING, 2003), as profissionais mencionaram: a capacidade crítica de leitura da realidade, o acionamento da rede de proteção social em seus diferentes níveis e complexidades; realizar articulação com os diferentes setores da sociedade; e ter responsabilidade ética e compromisso com o usuário. Isso se expressa nas seguintes falas:

O Serviço Social estimula e realiza reflexões sobre: as especificidades do Serviço Social na saúde e o Projeto Ético-Político da profissão; o controle social em relação aos serviços e legislações que se relacionam à essa questão; o funcionamento da rede de saúde e das políticas inclusivas do DF. (assistente social $1 ., 2018)$

O profissional de Serviço Social possui a capacidade de leitura da realidade para identificar as demandas postas; habilidade para estar diante e intervir em questões limites da vida humana; trabalhar em equipe interdisciplinar. (assistente social 2.,2018)

O sigilo profissional é outra possibilidade que deve estar atrelado a prática profissional e isso deve ser esclarecido junto ao usuário, sempre que necessário. É necessário que o profissional tenha a capacidade de fazer uma leitura da realidade, baseada nos princípios éticos da profissão. (assistente social 3.,2018)

Como se vê, muitos são os limites que prejudicam a atuação de qualidade dos profissionais do Serviço Social, tais como: falta de verbas, falta de estrutura adequada, insuficiência de profissionais, tratamento inadequado, dificuldade de compreensão sobre o funcionamento e organização da rede de serviço; inexistência de medicação específica para tratamento da dependência na rede pública, entre outros.

No entanto se focarmos unicamente nos problemas, desafios e nos limites, e não aprendermos as diversas possibilidades corre-se o risco de cair no que Iamamoto (2000) já assinalava, como sendo a prática fatalista, compreendida como aquela intervenção de um assistente social acomodado, que reconhece as dificuldades existentes mas lamenta não poder modificar o quadro presente. Sobre isso, destaca-se a fala de uma assistente social:

Muitos profissionais que atuam no campo, ainda que em meio a todos estes limites, viabilizam estratégias que causam impacto significativo na realidade das pessoas. Além disso, conscientizam a população sobre as dificuldades vivenciadas $e$ reivindicam não somente dentro de suas instituições, como fora, melhores condições de trabalho e assistência aos usuários. (assistente social 3.,2018)

Por tudo isso, fica a reiteração de que apesar dos problemas de todas as ordens, o assistente social pode propor e fundamentar sua prática na perspectiva do para além da garantia de direitos e voltar-se para a construção de uma nova sociabilidade, no respeito à 
autonomia dos usuários e na compreensão destes como sujeitos do processo bem como na importância da sua vinculação com os serviço de saúde.

\section{Balanço analítico dos dados}

Neste tópico será apresentado uma breve análise crítica de alguns dos dados descritos anteriormente, com vistas a entender o que a fala dos usuários revela sobre a questão central desta monografia: Fatores que interferem no processo de adesão sob a perspectiva dos próprios usuários.

A participação familiar foi unânime em todas as falas como sendo essencial na adesão ao tratamento. Apesar de concordarmos com o dado e as literaturas especializadas afirmarem o mesmo, de acordo com Mioto (2010) o fato da família e das formas de intervenção com famílias não ser problematizada e trabalhada dentro de uma apreensão crítica e de totalidade afeta profundamente o campo da prática profissional.

Nessa direção, os profissionais do Serviço Social devem constantemente refletir sobre o papel da família e tomar o cuidado em não a responsabilizar totalmente pela situação em que seus membros se encontram, o que corrobora para o desmascaramento do papel que o Estado tem de assumir frente a esta questão.

Segundo a autora supracitada, no que se refere a interpretação da demanda da família e consequentemente dos seus membros, deve-se ter a compreensão de que as demandas são expressões de necessidades, decorrentes sobretudo da desigualdade social própria da organização capitalista. E, portanto, não podem ser mais tomados como problemas de família.

Além disso, outro dado preponderante verbalizado pelos próprios usuários é no que se refere à própria vontade do usuário em mudar sua situação, porém sabe-se que embora o paciente reconheça minimamente que precisa rever seu quadro e buscar tratamento, o dependente da substância psicoativa necessita ter primeiro um desenvolvimento cognitivo saudável quanto à necessidade de tratamento e depois uma condição comportamental, o que fica claro a partir da experiência de estágio, no qual muitos dos usuários participantes da pesquisa, apresentavam limitações cognitivas e algumas comorbidades psiquiátricas.

Considerando isso, nessa direção, apresenta-se alguns dos dados obtidos acerca dos fatores de adesão: sob a ótica dos próprios usuários:

- Apoio familiar compreendido como uma postura que se dá em todo o processo de tratamento;

- Profissionais comprometidos com a temática de álcool e outras drogas;

- Vontade própria do paciente em mudar sua situação; 
- Socialização de informações para a sociedade, tanto a respeito da existência de tratamentos especializados gratuitos e na difusão de estudos que mostram que a questão da dependência é uma doença complexa e não uma questão moral;

- Tratamento humanizado e sem estigmas por parte dos profissionais de saúde, aqui especialmente, dos assistentes sociais.

Por fim, quanto aos desafios e as possibilidades do trabalho do assistente social é interessante destacar os seguintes aspectos:

Desafios: Omissão do Estado frente à temática e a falta de verbas que inviabiliza um tratamento de qualidade; Fragilidade no acesso, comunicação e atendimento com a rede de saúde; Possibilidades: A capacidade de leitura crítica da realidade para identificar as demandas postas na sociedade; Atuação profissional pautada na ética e na eliminação de estigmas; compreensão da questão do uso de drogas como uma expressão da Questão Social. 


\section{CONSIDERAÇÕES FINAIS}

A pesquisa teve como objetivo geral analisar os fatores de adesão que interferem no processo de tratamento dos usuários do SEAD sob a perspectiva dos próprios sujeitos e frente à problemática do álcool e outras drogas no contexto da Questão Social. Para tal, foi empreendido um levantamento bibliográfico sobre a temática, a realização de um GF para a coleta dos dados e a utilização da metodologia qualitativa para a análise dos resultados obtidos.

A justificativa para tal pesquisa se deu a partir da experiência de estágio supervisionado obrigatório no SEAD e na consideração da complexidade do tema de uso de drogas na atualidade. Considerando esta prática como expressão da Questão Social e que não existiu nenhuma sociedade sem o uso de drogas, faz-se de extrema relevância o aprofundamento teórico e debate sobre a temática, especialmente no que se refere à dependência de substâncias psicoativas que é uma questão de Saúde Pública.

Além disso, considera-se também que o uso de drogas não é um fenômeno exclusivo da sociedade contemporânea. Pelo contrário, é um fenômeno que está intrínseco ao desenvolvimento de toda a humanidade.

Vale destacar que para a concretização do objetivo deste trabalho foi imprescindível uma contextualização teórica sobre a política de saúde além dos resgates históricos referente à política de saúde mental destacando o uso de drogas nesse cenário e explicitando o quanto as especificidades do uso de SPA's está relacionada com a Política Social e nos marcos da Seguridade Social. Além disso, foi necessária uma imersão sobre o debate concernente ao fenômeno das drogas correlacionando com os determinantes sociais da saúde e a sua vinculação com o Serviço Social.

Diante disso e retomando a questão central desta monografia, aqui se deteve principalmente o debate sobre os fatores de adesão, isto é, o que ajuda ou não o sujeito a permanecer no tratamento para a dependência de drogas.

Dentre alguns dos resultados apresentados por meio do discurso dos participantes desta pesquisa, é significativo destacar que o apoio familiar, tem a sua relevância, em razão de que é na família que os sujeitos encontram um lugar de acolhimento e de pertencimento. No entanto, sabe-se que discutir a questão família é algo complexo e permeado por algumas determinações históricas, culturais e políticas, e que além de tudo, existem famílias tóxicas para o convívio dos seus membros. 
Além de tudo, foi recorrente também nas falas dos usuários a questão da vontade própria do paciente em mudar a sua situação. O que nos evidencia o fato de apesar de ser um fator relevante, por si só, não tem impacto considerável no processo de tratamento. Uma vez que como visto no decorrer deste trabalho, a dependência química torna o indivíduo impotente diante da possibilidade de controlar o consumo de drogas, e isto passa a ser prioridade em detrimento de outras atividades.

O Serviço Social nesse lócus tem um papel importantíssimo pois compreendendo a questão das drogas como expressão da Questão Social intervém de modo que viabiliza os direitos sociais destes sujeitos. Assim, ao assistente social cabe aprofundar o conhecimento acerca das drogas e da crítica ao proibicionismo articulando nesse sentido estes temas ao Projeto Ético-Político Profissional que determina o reconhecimento da liberdade como valor ético central, bem como na prestação de serviços de qualidade à população usuária.

Por fim, faz-se necessário reconhecer e destacar que muitos são os limites resultantes da sociedade burguesa e que implicam de forma negativa para a materialização do SUS no sentido da universalização do acesso aos serviços de saúde e dos direitos sociais e também na prática profissional do assistente social no lócus álcool e outras drogas. No entanto, é preciso recordar que a realidade está em constante movimento, o real é dialético e contraditório e embora a sociedade esteja permeada pela existência de numerosos obstáculos, sejam eles econômicos, sociais, políticos e ideológicos nada está perdido. 


\section{REFERÊNCIAS BIBLIOGRÁFICAS}

ACSELRAD, Gilberta. A educação para a autonomia: a construção de um discurso democrático sobre drogas. IN: ACSELRAD (org.). Avessos do prazer: droga, AIDS e direitos humanos. Rio de Janeiro: Fiocruz, 2000.

ALMEIDA FILHO, Naomar de; COELHO, Maria Thereza Ávila; PERES, Maria Fernanda Tourinho. O conceito de saúde mental. USP, São Paulo, p.100-125, nov. 2009.

ALVES, Álvaro Marcel. O método materialista histórico dialético: alguns apontamentos sobre a subjetividade. Revista de Psicologia da UNESP, São Paulo, p.1-13, 10 de mar. 2010.

AMARANTE, P. D. C. (1997). Loucura, cultura e subjetividade: conceitos e estratégias, percursos e atores da Reforma Psiquiátrica Brasileira. In S. Fleury (Org.), Saúde e Democracia: a luta do CEBES (pp. 163-185). São Paulo: Lemos Editorial

BARDIN, L. Análise de conteúdo. São Paulo: Edições 70. 2011.

BARROCO, Maria Lúcia, 2001. Ética e Serviço Social: Fundamentos Ontológicos. São Paulo: Cortez Editora. Interações: Sociedade. 2001.

BASTOS, F. I.; COTRIM, B. C. O consumo de substâncias psicoativas entre jovens brasileiros: dados, danos e algumas propostas. In: JOVENS ACONTECENDO NAS TRILHAS DAS POLÍTICAS PÚBLICAS. Brasília, 1998.

BEHRING, Elaine Rossetti. Brasil em Contrarreforma: desestruturação do Estado e perda de direitos. São Paulo: Cortez, 2003.

BISNETO, José Augusto. Serviço Social e Saúde Mental: Uma análise institucional da prática. $2^{a}$ ed. São Paulo: Cortez, 2009. f. 222.

BOBBIO, Noberto; MATTEUCCI, Nicola; PASQUINO, Gianfranco. Dicionário de Política. $11^{\text {a }}$ edição. Brasília, DF. Editora Universidade de Brasília. 1998. V.1

BOSCHETTI, Ivanete. Expressões do conservadorismo na formação profissional. Serviço Social, São Paulo, p.637-651, 28 jul. 2015. Disponível em: <http://www.scielo.br/pdf/sssoc/n124/0101-6628-sssoc-124-0637.pdf>. Acesso em 18 mai. 2018.

BRASIL, Ministério da Saúde do. Saúde mental no SUS: os centros de atenção psicossocial. Ministério da Saúde, Secretaria de Atenção à Saúde, Departamento de Ações Programáticas Estratégicas. - Brasília, 2004, 86.

BRASIL. Constituição (1988). Artigo 144 Segurança Pública. Constituição da República Federativa do Brasil. Brasília, DF: Senado Federal: Centro Gráfico, 1988. 292 p.

BRASIL. Constituição (1988). Artigo 196, seção II. Constituição da República Federativa do Brasil. Brasília, DF: Senado Federal: Centro Gráfico, 1988. 292 p. 
BRASIL. Ministério da Saúde. Secretaria de Atenção à Saúde. Departamento de Ações Programáticas Estratégicas. Guia estratégico para o cuidado de pessoas com necessidades relacionadas ao consumo de álcool e outras drogas: Guia AD/Ministério da Saúde, Secretaria de Atenção à Saúde, Departamento de Ações Programáticas Estratégicas. Brasília, 2015.

BRASIL. Ministério da Saúde. Secretaria de Atenção à Saúde. Departamento de Atenção Básica. Acolhimento à demanda espontânea. Brasília, 2011. 56 p. (Série A. Normas e Manuais Técnicos). (Cadernos de Atenção Básica n. 28, v. 1. 2011.

BRASIL. Ministério da Saúde. Secretaria de Atenção à Saúde.DAPE. Coordenação Geral de Saúde Mental. Reforma psiquiátrica e política de saúde mental no Brasil. Documento apresentado à Conferência Regional de Reforma dos Serviços de Saúde Mental: 15 anos depois de Caracas. OPAS. Brasília, novembro de 2005.

BRAVO, Maria Inês e SOUZA, Rodriane de Oliveira. Conselhos de Saúde e Serviço Social: luta política e trabalho profissional. In: Ser Social - Revista do Programa de Pós-graduação em política Social (10). Brasília: UnB, 2001.

BREDOW, Suleima Gomes; DRAVANZ, Glória Maria. Atuação do Serviço Social na Saúde Mental: entre os desafios e perspectivas para efetivação de uma política intersetorial, integral e resolutiva. Textos \& Contextos, Porto Alegre, v. 9, n. 2, p. 229-243, ago./dez. 2010.

BRITES, C. M. Ética e uso de drogas: uma contribuição da ontologia social para o campo da Saúde pública e da redução de danos. 148f. 2006. Tese (Doutorado em Serviço Social). Pontifícia Universidade Católica de São Paulo, São Paulo.

BRITES, Cristina Maria. Psicoativos (drogas) e Serviço Social: uma crítica ao proibicionismo. São Paulo: Cortez, 2017.

BUCHER, Richard. Drogas e drogadição no Brasil. Porto Alegre: Artes Médicas, 1992.

BUSS, Paulo; PELLEGRINI FILHO, Alberto. A saúde e seus determinantes sociais. Physis: Revista Saúde Coletiva. Rio de Janeiro. 17(1): 77-93, 2007.

CEBRID - Centro Brasileiro de Informações sobre Drogas Psicotrópicas (2015).

CFESS. Residência em Saúde e Serviço Social. Brasília. 2017. Acesso em: 26 de junho de 2018.

CHAIM, Carolina Hanna; BANDEIRA, Kercya Bernardes P.; DE ANDRADE, Arthur Guerra. Fisiopatologia da dependência química. Revista de Medicina, v. 94, n. 4, p. 256$262,2015$.

CRIVES, M. N.S.; DIMENSTEIN, M. Sentidos produzidos acerca do consumo de substâncias psicoativas por usuários de um programa público. Saúde e Sociedade, São Paulo, v.112,1n.2,1p.26-37,1dez. 2003. 
EBSERH. Carta de Serviço. Ministério da Educação. Acesso em: 20 de junho de 2018.

EDWARDS, G.; MARSHALL, E. J. \& COOK, C. C. H. O tratamento do alcoolismo: um guia para os profissionais de Saúde. 3. ed. Porto Alegre: Artes Médicas, 1999.

FALEIROS, Vicente de Paula. Globalização, correlação de forças e Serviço Social. São Paulo: Cortez, 2013.

FARIA \& VARGAS. Acolhimento: concepções e práticas dos profissionais que compõem as equipes interdisciplinares do Hospital Universitário de Brasília, 2017.

FERREIRA, Aline C.Z., BORBA, Letícia O., CAPISTRANO, Fernanda C., et al. Fatores que interferem na adesão ao tratamento de dependência química: percepção de profissionais da saúde. Revista Mineira de Enfermagem. Minas Gerais, v. 19, n. 2, jan./mar., 2015.

FREIRE, Paulo. Pedagogia da autonomia: saberes necessários à prática educativa. São Paulo: Paz e Terra, 2011.

GOFFMAN E. Estigma. Notas sobre a manipulação da identidade deteriorada. 2. ed. Rio de Janeiro: Zahar; 1978.

GONÇALVES, A.M. SENA, R.R. A reforma psiquiátrica no Brasil: contextualização e reflexos sobre o cuidado com o doente mental na família. Rev Latino-am Enfermagem 2001 março; 9 (2): 48-55.

GUIMARÃES, Ricardo Amorim: O Serviço Social e os seus instrumentos e técnicas: Uma análise da percepção da Abordagem com Grupo no meio profissional do assistente social. Trabalho de Conclusão de Curso. Universidade de Brasília, Departamento de Serviço Social, 2013.

IAMAMOTO, M. Serviço Social em tempo de capital fetiche. São Paulo: Cortez, 2007

IAMAMOTO, Marilda V. O Serviço Social na Contemporaneidade: trabalho e formação profissional. 52. Ed. São Paulo: Cortez, 2001.

IERVOLINO, SA.; PELICIONI, MCF. A utilização do grupo focal como metodologia qualitativa na promoção da saúde. Rev Esc Enf USP, v. 35, n.2, p.115-21, jun, 2001.

JUNGERMAN F.S. LARANJEIRA R. Entrevista motivacional: bases teóricas e práticas. São Paulo: CD UNIAD - UNIFESP, 1999.

MATUMOTO S. O acolhimento: um estudo sobre seus componentes e sua produção em uma unidade da rede básica de serviços de Saúde. 1998.

MELMAN, J. Família e doença mental: repensando a relação entre profissionais de saúde e familiares. São Paulo: Escrituras, 2006. 
MINAYO, Maria Cecília de Souza. O desafio do conhecimento. 11 ed. São Paulo: Hucitec, 2008.

MIOTO, Regina Célia. Palestra Família, trabalho com famílias e Serviço Social. SERV. SOC. REV., LONDRINA, V. 12, N.2, P. 163-176, JAN./JUN. 2010 Disponível em: 〈http://www.uel.br/revistas/uel/index.php/ssrevista/article/view/7584/6835> >. Acesso em: 20 de abril de 2019.

MOISÉS RAR. Midiatização do crack e estigmatização: corpos habitados por histórias e cicatrizes. Interface. (Botucatu) [Internet]. 2014; 18(49): 363-76. Disponível em: $<$ http://www.scielo.br/scielo.php?script=sci_arttext\&pid=S1414-

32832014000200363\&lng=en\&nrm=iso. Acesso em: 15 maio de 2018.

MOTA, Ana Elizabete. O mito da assistência social. Ensaios sobre Estado, política e sociedade. São Paulo: Cortez, 2009.

MUNDIM, Andressa C. O. Reforma Psiquiátrica e Saúde Mental no Brasil: uma reflexão sobre o terror demonstrado no filme "Em nome da razão". Maceió, Alagoas. Rede humaniza. SUS.2017.Disponivel em: <http://redehumanizasus.net/96483-reformapsiquiatrica-e-saude-mental-no-brasil-uma-reflexao-sobre-o-terror-demonstrado-no-filme-emnome-da-razao/>. Acesso em: 04 jun. 2019.

NASCIMENTO, Geysa Cristina Marcelino; SCORSOLINI-COMIN, Fabio; PERES, Rodrigo Sanches. Saúde Mental no Sistema Único de Saúde: mapeamento das contribuições dos Centros de Atenção Psicossocial. SMAD, Rev. Eletrônica Saúde Mental Álcool Drog. (Ed. port.) Ribeirão Preto, v. 9, n. 2, p. 95-102, ago. 2013. Disponível em http://pepsic.bvsalud.org/scielo.php?script=sci_arttext\&pid=S180669762013000200008\&lng=pt\&nrm=iso . Acesso em: 31 maio 2018.

OLIVEIRA MS, Szupszynski KPDR, Diclemente C. Estudo dos estágios motivacionais no tratamento de adolescentes usuários de substâncias psicoativas ilícitas. Psico (Porto Alegre). 2010; 41(1):40-6

OLIVEIRA, Ana Carolina; GUEDES, Cristiano. Serviço Social e desafios da ética em pesquisa: um estudo bibliográfico. Rev. katálysis[online]. 2013, vol.16, n.spe, pp.119-129. ISSN 1982-0259.

OLIVEIRA, Maria; SANTO, Eniel. A relação entre os determinantes sociais da saúde e a questão social. Saúde e desenvolvimento. Uninter. v. 2, n. 2. 2013.

PAIM JS. Uma análise sobre o processo da Reforma Sanitária brasileira. Rev. Saúde em Debate. 33(81):27-37. 2009.

PAIVA, Carlos Henrique Assunção; TEIXEIRA, Luiz Antonio. Reforma sanitária e a criação do Sistema Único de Saúde: notas sobre contextos e autores. História, Ciências, Saúde - Manguinhos, Rio de Janeiro, v.21, n.1, jan.-mar. 2014, p.15-35

RABELO, Ionara V. M.; TAVARES, Rosana C.; FARIAS, Yuza R. Prefácio. In: et al. (Orgs.). Olhares: experiências de CAPS. Goiânia: Editora Kelps, 2009. 
FERNANDES, Rafaela Bezerra. - O IMPACTO DA PRIVATIZAÇÃO DO HOSPITAL UNIVERSITÁRIO DE BRASÍLIA NO FAZER PROFISSIONAL DOS ASSISTENTES SOCIAIS. TRABALHO DE CONCLUSÃO DE CURSO, DEPARTAMENTO DE SERVIÇO SOCIAL, UNB 2014.

REIS, Helca F.T., MOREIRA, Thais O. O CRACK NO CONTEXTO FAMILIAR.

RIBEIRO MS, Ribeiro LC, Garcia MA, Souza GF, Sousa KDC, Nogueira RB. Fatores associados à adesão a um programa de tratamento de alcoolistas.

RONZANI, Telmo Mota; FURTADO, Erikson Felipe. Estigma social sobre o uso de álcool. J. bras. psiquiatr. Rio de Janeiro, v. 59, n. 4, p. 326-332, 2010. Disponível em <http://www.scielo.br/scielo.php?script=sci_arttext\&pid=S0047-

20852010000400010\&lng=en\&nrm=iso > . Acesso em 31 de maio de 2018.

SANTOS, B. S. Um discurso sobre as ciências. $5^{\text {a }}$ ed. São Paulo: Afrontamento, 1991

SANTOS. E.T. O acolhimento como um processo de intervenção do Serviço Social.

SCHEFFER, Graziela; SILVA, Lahana G. Saúde mental, intersetorialidade e questão social: um estudo na ótica dos sujeitos. Serv. Soc. Soc., São Paulo, n. 118, p. 366-393, abr./jun. 2014. Disponível em: 〈http://www.scielo.br/pdf/sssoc/n118/a08n118.pdf >. Acesso em: 20 de abril de 2019.

SILVA, Natalia Meritello da Luz. O modelo de avaliação social da pessoa com deficiência no Brasil: dilemas e contradições / Natalia Meritello da Luz Silva. -- 2018. 113 f.: tab.

Sociedade em Debate, 22(1): 261-289, 2016 O Serviço Social e a temática droga. Mirian Cátia Vieira Basílio, Denadai Maria Lúcia Teixeira Garcia.

SOLLERO, L. Farmacodependência. Rio de Janeiro. Agir; 1979.

SOUZA LGS, Pinheiro LB. Oficinas terapêuticas em um Centro de Atenção Psicossocial álcool e drogas. Universidade Federal de Santa Catarina. Departamento de Serviço Social.

TRABUCO, Karem E.O., SANTOS, Diajne S. DA REFORMA SANITÁRIA A REFORMA PSIQUIÁTRICA: os movimentos sociais e a conquista de direitos. 2015. Disponível em: < http://www.joinpp.ufma.br/jornadas/joinpp2015/pdfs/eixo3/da-reformasanitaria-a-reforma-psiquiatrica-os-movimentos-sociais-e-a-conquista-de-direitos.pdf $>$ Acesso em: 31 de maio de 2018.

VASCONCELOS, A. M. A prática do Serviço Social: Cotidiano, formação e alternativas na área da Saúde. 3. ed. São Paulo: Cortez, 2006.

VEIGA L. \& Gondim, S.M.G. (2001). A utilização de métodos qualitativos na ciência política e no marketing político. Opinião Pública. 2(1), 1-15.

VELOSO, Laís Helena Pinto; ABREU, Renata. A Questão Social das Drogas e a Prática do Serviço Social (uma proposta de afirmação de direitos e de cidadania). (2004). 
WOERNER, C. B. Serviço Social e Saúde Mental: atuação do assistente social em comunidade terapêutica. 2015

WORLD HEALTH ORGANIZATION. Adhrence to long-term therapies: evidence for action. Geneva: World Health Organization; 2003

\section{ANEXOS}

TERMO DE AUTORIZAÇÃO E PERGUNTAS DO GRUPO FOCAL

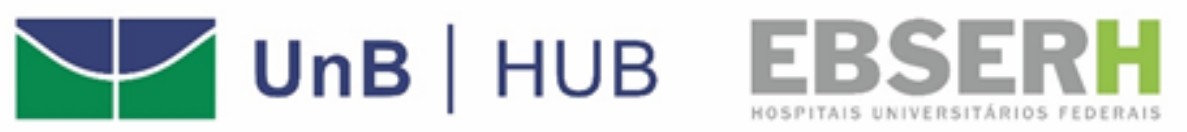

\section{Hospital Universitário de Brasília - HUB/EBSERH}

Serviço de Estudos e Atenção a Usuários de Álcool e outras Drogas - SEAD

Discente: Caio Henrique Inácio Ferreira

Prof. ${ }^{a}$. Dr ${ }^{\mathrm{a}}$ Karen Santana de Almeida Vieira.

Autorizo a gravação em áudio do grupo focal realizado no Serviço de Estudos e Atenção a Usuários de Álcool e outras Drogas - SEAD com a finalidade acadêmica, e sob a condição de que não seja identificado o meu perfil e nem divulgado o meu nome.

Esta AUTORIZAÇÃO foi concedida mediante o compromisso do pesquisador em garantirme os seguintes direitos:

1. poderei ler a transcrição de minha gravação;

2. os dados coletados serão usados exclusivamente para gerar informações para a pesquisa;

3. minha identificação não será revelada em nenhuma das vias de publicação das informações geradas;

4. qualquer outra forma de utilização dessas informações somente poderá ser feita mediante minha autorização;

5. serei livre para interromper minha participação na pesquisa a qualquer momento e/ou solicitar a posse da gravação e transcrição de minha entrevista

Brasília, dezembro de 2018. 
Assinatura do participante da pesquisa

\section{Assinatura do pesquisador responsável}

\section{UnB|HUB EBSERH}

Hospital Universitário de Brasília - HUB/EBSERH

Serviço de Estudos e Atenção a Usuários de Álcool e outras Drogas - SEAD

Discente: Caio Henrique Inácio Ferreira

Prof. ${ }^{a}$. Dr ${ }^{\mathrm{a}}$ Karen Santana de Almeida Vieira.

\section{DESENVOLVIMENTO DO GRUPO FOCAL}

1. Abertura do grupo - Recepção, agradecimento pela participação, apresentação do pesquisador e objetivo da pesquisa;

2. Apresentação dos participantes entre si - Será utilizada a dinâmica de dupla, em que os participantes apresentam o colega ao lado. (dinâmica interativa;

3. Esclarecimentos acerca da dinâmica de discussão participativa - Informações acerca do desenvolvimento do grupo

Guia de temas (5 perguntas que nortearão o grupo focal).

1) O que vocês pensam sobre o fato de as pessoas usarem álcool e outras drogas e quais são os problemas que vocês acham que os usuários de substâncias psicoativas enfrentam?

2) O que te motivou a buscar tratamento? Você pediu ajuda para alguém? Quem? Como foi?

3) O que você acha do tratamento que é oferecido aqui? Qual a sua avaliação sobre o tratamento?

4) Quais foram as dificuldades que vocês encontraram no início do processo de tratamento?

5) Na sua opinião o que ajudaria as pessoas usuárias de álcool e outras drogas a aderirem ao tratamento? 


\section{$\Psi$ UnB | HUB EBSERH}

Tema da monografia: Fatores de adesão no processo de tratamento dos usuários do $\mathrm{SEAD} / \mathrm{HuB}$

Discente: Caio Henrique Inácio Ferreira

Questionário - A atuação do Serviço Social frente a questão do uso de álcool e outras drogas

1) Qual a importância do Serviço Social frente a questão do álcool e outras drogas?

2) Em que consiste o trabalho do assistente social no SEAD?

3) Quais os limites e possibilidades do trabalho do assistente social no tratamento realizado pelo SEAD?

4) $\mathrm{Na}$ sua opinião, quais os fatores que mais influenciam para o usuário aderir ou não ao tratamento aqui?

5) Como se dá a abordagem da redução de danos frente a questão do uso de álcool e outras drogas? Tem casos que não é possível? 